\title{
CHRISTIANITY IN CHINA
}

\author{
NESTORIANISM \\ ROMAN CATHOLICISM
}

PROTESTANTISM

BY

JAMES LEGGE

PROFESSOR OF THE CHINESE LANGUAGE AND LITERATURE IN THE UNIVERSITY OF OXFORD

\section{Eondon}

TRÜBNER \& CO., 57 AND 59, LUDGATE HILL I 888

Price 2s. 6d.

KELLY \& WALSH, LIMITEO,

Rooksellers, Publishers,

Stationens and Printers,

SHANGHAI. 
To Dons Peacuen

1109 Soutt 6 thatris

Pruaduphria

76 s

Amerca

fum Eloro

O. En. Custoño

Chevo 


\title{
THE NESTORIAN MONUMENT
}

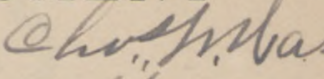

\author{
OF HSÎ-AN FÛ \\ IN SHEN-HSî, CHINA \\ RELATING TO
}

THE DIFFUSION OF CHRISTIANITY IN CHINA

IN THE SEVENTH AND EIGHTH CENTURIES

WITH

THE CHINESE TEXT OF THE INSCRIPTION, A TRANSLATION, AND NOTES

AND

A LECTURE ON THE MONUMENT

With a Sketch of subsequent Christian Missions in China and their present state

BY

JAMES LEGGE

PROFESSOR OF THE CHINESE LANGUAGE AND LITERATURE IN THE UNIVERSITY OF OXFORD

\section{EOndon}

TRÜBNER \& CO., 57 AND 59, LUDGATE HILL 
gohnt Aarps, anconn Clefao thina $26 / 0 / 90$.

OXford
HORACE HART, PRINTER TO 


\section{PREFA C E.}

I HAD long recognised the importance of the Hsî-an Fû monument, and the inscription on it had often engaged my attention. Towards the end of last year two rubbings or facsimiles of it were submitted to me, one of them more complete than I had ever seen before, showing not only the writing on the face, but also the long lists of names, mostly in Syriac but partly in Chinese, on the two sides. I made a fresh study of the inscription, in the course of which it occurred to me that there were some things to be said on it which had not been said already,-things not unimportant for the general public, and specially important for parties interested, like myself, in the prosecution and conduct of Missions in China. I resolved in consequence to give a public Lecture on the monument here in Oxford, and afterwards to print it.

In translating the inscription afresh I enjoyed many advantages. Most of the versions already made were accessible to me. I may specify the two translations in Kircher's China Illustrata; that of Semedo; the two of Bishop Visdelou, with his many notes, in one of the supplementary volumes to $\mathrm{B}$. D'Herbelot's Bibliothèque Orientale (A la Haye, I779); those of Dr. Bridgman and of P. Dalquié, both in the Chinese Repository for May, I845; that of M. Léontiewski, as translated from Russian into French by M. C. Marchal de Lunéville (Paris, 1853); that of Mr. A. Wylie, with all his notes; and that of M. Pauthier (1858). In all of these-in some more, in some less-there was room both for correction and improvement. I may say that my own translation was made in the first place quite independently, and that nothing was subsequently changed in it without mature deliberation.

In studying the Chinese text in my two facsimiles, 
which of course agreed exactly, I was surprised to find that in all the printed copies of it there were many errors. Of those in the China Illustrata I have spoken in the Lecture, and they were naturally reproduced by Dr. Bridgman in the Chinese Repository. The text in Wang Ch'ang's great collection of Inscriptions is much superior to Kircher's, but still not free from inaccuracies, which re-appear in Pauthier. It seemed desirable that I should annex to my translation a more correct Chinese text than had previously been printed.

The easiest way to do this would have been by photography, and we have a fine specimen of what can thus be accomplished by the representation of the Inscription in the and edition of Col.Yule's Travels of Marco Polo. But I was anxious that readers and especially students of Chinese should have a text in larger type, which they might read with ease, and without having their attention distracted by the peculiar forms of many of the characters in the T'ang writing of the Inscription. These do not disguise the characters from a scholar familiar with Chinese, but they are troublesome to men in the earlier stages of their progress. But for the resources of the Clarendon Press, the printing of the text as I wished to see it could not have been secured. If there be still any inaccuracies in it, they must be put down to my own want of sufficient watchfulness over the compositors.

I have thus detailed the reasons for the appearance of this little publication, and have only further to acknowledge my great obligation to Mr. D. S. Margoliouth, of New College, and to the Rev. F. H. Woods, St. John's College, for their assistance in the transcription and translation of the Syriac on the monument. The lists of names on the two sides it did not seem worth while to reproduce; they are referred to in a note at the end of the Translation.

OXFORD,

J. L.

March 28, I 888. 

MONUMENT (COMMEMORATING) THE DIFFUSION OF THE ILLUSTRIOUS RELIGION OF TÂ TS'IN IN THE MIDDLE KINGDOM.

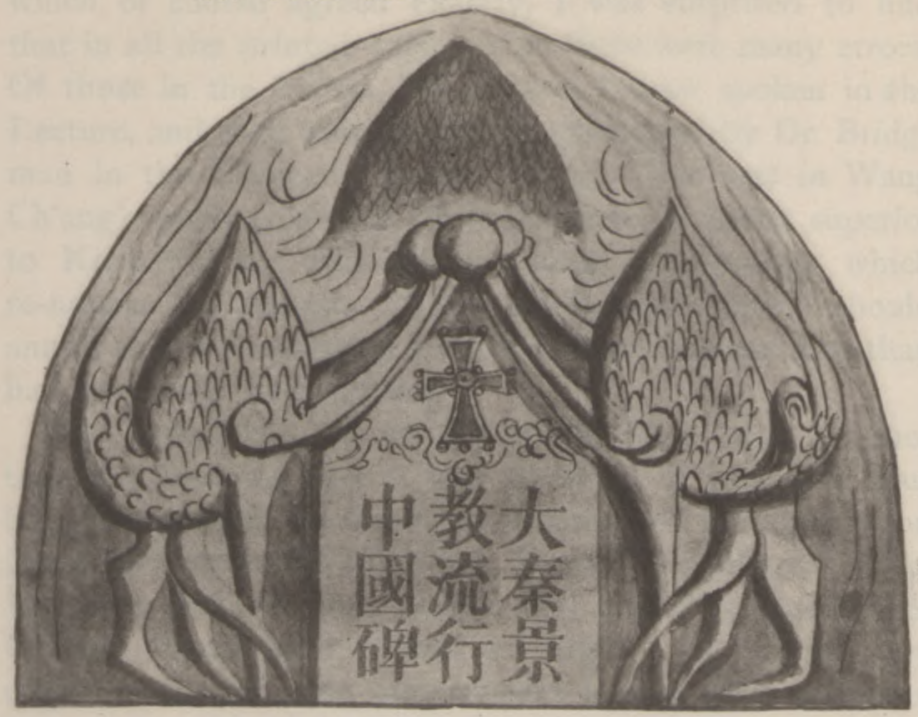

HEAD OF THE MONUMENT.

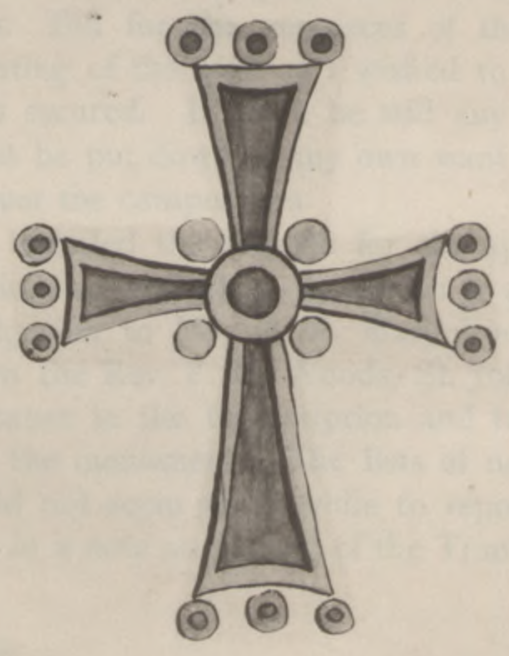

THE CROSS IMMEDIATELY ABOVE THE NAME OF THE MONUMENT. 
TEXT AND TRANSLATION

OF THE

MONUMENT. 


\section{二碑國中行流教景}

而 奥

造若。

化、常

妙 然大

咱臭泰流

聖寂寺 行

以 先 僧

元 先 景

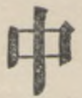

尊而浄

者。无 述

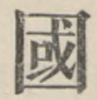

其元货石管

唯 㕷 $R$

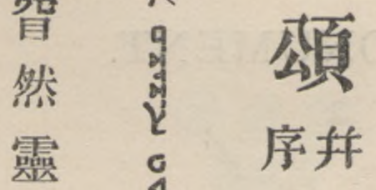

我虛。

三 後

一 後 g

妙而 证

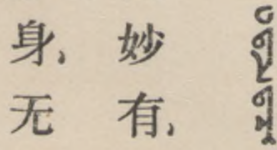

元 㧾

है 
THE EULOGISTIC VERSES ON THE STONE MONUMENT (COMMEMORATING) THE DIFFUSION OF THE ILLUSTRIOUS $^{1}$ RELIGION IN THE MIDDLE KINGDOM, WITH PREFATORY NOTICES.

HANDED DOWN BY ChInG-TSING, A PRIEST OF THE TÂ TS'IN MONASTERY.

(In Syriac.) Adam, Presbyter and Chorepiscopos, and Papas of CHINA.

I. I. IT is acknowledged ${ }^{2}$ that there was One, unchangeable, true, and still, the First and unoriginated ; incomprehensible in His intel-

The Divine ligence and simplicity; the Last and mysteriously Being. existing; Who, with His hands operating in the mysterious (abyss of space), proceeded to create ${ }^{3}$, and by His spirit to ${ }^{4}$ give existence to all the Holy ones, Himself the great adorable ;-was not this our Eloah ${ }^{5}$, with His marvellous being, Threein-One, the unoriginated True Lord?

${ }^{1}$ It has been made an objection to the genuineness of the monument that the form of the characters and style of the composition are so much akin to the writing and style of the present day. But the same objection may be made to other inscriptions of the same date, and even of dynasties older than the T'ang. No one familiar with the character and literature of the country would be likely to make it, still there are some of the characters of an unusual form, though rarely unexampled. To two or three, not previously pointed out, attention will be found drawn in the present edition of the Chinese Text. I wish here to notice the character translated 'Illustrious,' and which everywhere in the monument appears as 景 instead of 景. There is no doubt that they are two forms of the same character, but I have nowhere found their difference of form remarked upon, and it has escaped the observation of all the lexicographers, Chinese as well as foreign. The second, or common form, is the correct one; the $甘$, or symbol of meaning, is what it should be, and so is the 宗 (king), or phonetic symbol. The writer of this inscription uses 宗 for 京 through-

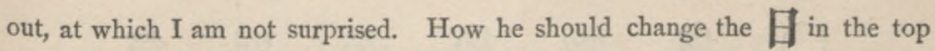
of the character into $\square$ surprises and perplexes me.

${ }^{2}$ The first three Books of the Shâ King begin in the same way. Bridgman's translation of the two Chinese characters by 'Now verily' is good.

${ }^{3}$ A difficult clause. Bridgman misreads 摳 in it, as if it were 樞 'a pivot,' 'an axis.'

${ }^{4}$ Compare the use of 妙 in the fifth Appendix to the Yî King, par. Io.

${ }^{5}$ The phonetization in Chinese of the Syriac term for God, equivalent to the Hebrew קils: 


\section{四碑國中行流教景}

役室是殫鐄 天 阿

役、有以施化地 羅

茫以三妄。海。開、訶

然淪百 鈿 $\bigcirc$ 日 欺。

無 二, 六 飾 渾 月 $\bigcirc$

得, 或十純 元運 判

煎 噚 五 精。之而十

迫 郝 種。間 性。畫 字

轉以肩平虚夜以

燒、邀隨大而作、定

積 福, 結 於不匠四

昧 或䡴。此盈, 成方。

亡 伐競 是素萬鼓

途。善織之蕩物。元

久以法中,之然風

迷 矯 羅。隙 心立 而

休人、或冥本初生

復。智指同無人、二

○虑物於希別氣

於營以彼嗜。賜暗

是 營, 託 非洎 良 空

思宗之乎和、易

情 或 內, 娑 令 而 
2. Having determined the four cardinal points in space as by the extremities of the character for ten $(十)^{1}$, He called into action the primordial wind, and produced the twofold ether ${ }^{2}$. The process of The dark void was changed, and heaven and earth Creation; especially of man. were opened out. The sun and moon revolved, and day and night commenced. Having formed and fashioned the myriad things, He then made the first man, specially conferring on him the harmony of all good qualities, and commanding him to have dominion over the ocean depths (now) transformed (into the earth) ${ }^{3}$.

3. Man's perfect original nature was void of all ambitious preoccupation; his unstained and capacious mind was free from all inordinate desire. When, however, Satan ${ }^{4}$ employed The Fall of his evil devices, a glamour was thrown over that pure Man, and its and fine (nature). A breach wide and great was made in its judgments of what was right, and it was drawn, as through an opening into the gulph of (Satan's) perversities ${ }^{5}$. In this way there arose (among men) $365^{6}$ different forms (of error), closely following one another, and treading in the same ruts, striving to weave the nets of their several ways. Some set up (material) things as the objects of their worship; some insisted on empty space without the (ethereal) duality; some offered prayers and sacrifices in order to obtain happiness; some boasted of their goodness, and arrogated it over others:-with their wisdom they anxiously tasked themselves, labouring with their fondest feelings; but all in vain. The heat of their distress was turned into a scorching flame. They made the darkness greater and lost their way; and after going long astray, they ceased any further search (for the truth).

4. Hereupon our Tri-une (Eloah) divided His Godhead ${ }^{7}$, and the Illustrious and Adorable Messiah ${ }^{8}$, veiling His true Majesty, appeared

${ }^{1}$ It is not necessary to suppose that the writer of the Inscription was thinking here of the 'cross,' a symbol of Christianity, as he does below in par. 5 .

${ }^{2}$ The cosmogony first of Tâoism, and then of the Sung and all subsequent Chinese philosophy.

${ }^{3}$ Literally, 'to sway the transformed seas.' The writer evidently had the first chapter of Genesis in his mind.

1 A phonetization of the Syriac, corresponding to the Hebrew

${ }^{5}$ A most difficult sentence to translate; but a fine example of the balancing of antithetic terms and phrases in Chinese composition.

${ }^{6}$ Why $3_{6}{ }_{5}$ ? Did the writer mean to say that the different sects or forms of error were as numerous as the days of the year?

${ }^{7}$ Literally, 'our Three-in-One divided His body (or person).' I must take 分 身 actively as expressing the act of the Tri-une. The peculiar dogma of Nestorius underlies the expression,- the dogma of 'two persons in Christ ;' one of the many vain attempts to fathom 'the great mystery of godliness.'

${ }^{8}$ Again, a phonetization of the Syriac name of the 'Messiah.' 
叫非

. Tार

謏

佔

달 Ais

相

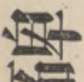
$-1$

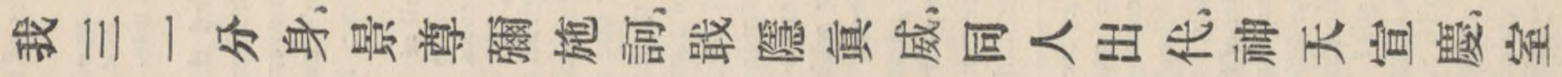

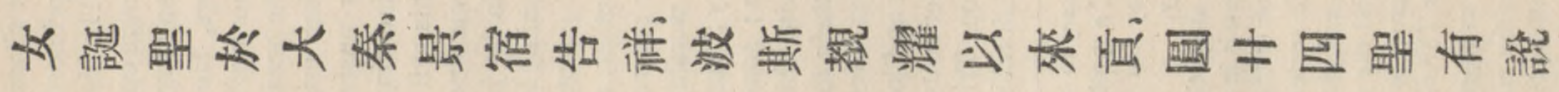

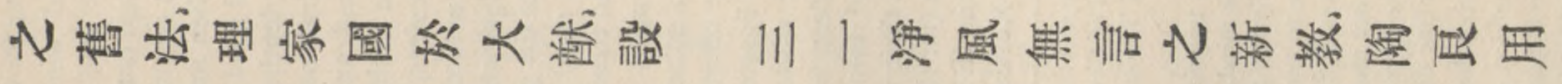

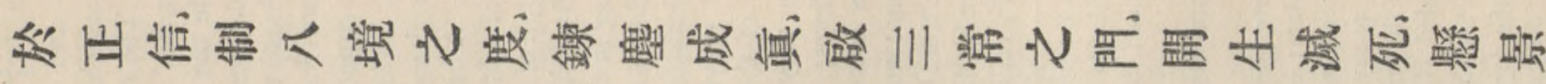

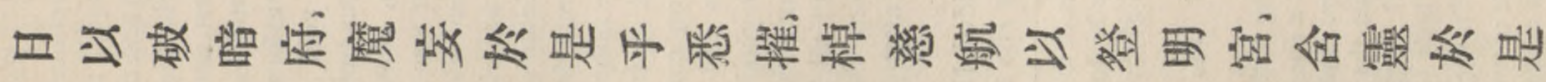

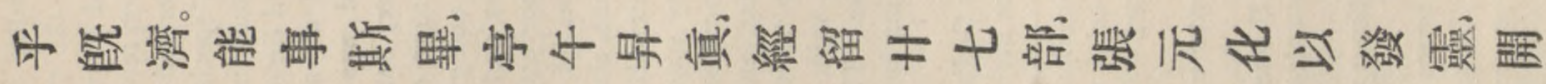

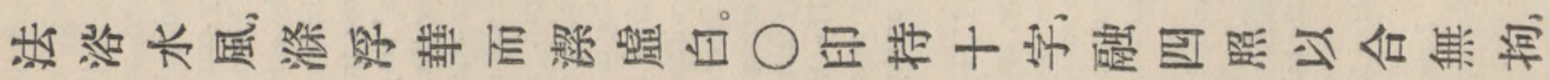


Advent and work of the

Messiah.

in the world as a man. Angels ${ }^{1}$ proclaimed the glad tidings. A virgin brought forth the Holy one in Tâ Ts in ${ }^{2}$. A bright star announced the felicitous event. Persians saw its splendour and came with tribute. He fulfilled the Old Law, as it was delivered by the twenty-four holy ones $^{3}$. He announced His great plans for the regulation of families and kingdoms ${ }^{4}$. He appointed His new doctrines, operating without words ${ }^{5}$ by the cleansing influence of the Tri-une. He formed in man the capacity of good-doing by the correct faith. He defined the measures of the eight (moral) conditions ${ }^{6}$, purging away the dust (of defilement) and perfecting the truth (in men). He threw open the gate of the three constant (virtues) ${ }^{7}$, thereby bringing life to light and abolishing death. He hung up the bright sun to break open the abodes of darkness. By all these things the wiles of the devil were defeated. The vessel of mercy ${ }^{8}$ was set in motion to convey men to the palace of light, and thereby all intelligent beings were conveyed across (the intervening space) ${ }^{9}$. His mighty work being thus completed, at noonday $\mathrm{He}$ ascended to His true (place). He left behind Him the twentyseven standard books ${ }^{10}$. These set forth the great conversion for the deliverance of the soul. They institute the washing of His Law by water and the spirit, cleansing away all vain delusions, and purifying men till they regain the whiteness of their pure simplicity ${ }^{11}$.

5. (His ministers) ${ }^{12}$ bearing with them the seal of the Cross ${ }^{13}$, diffuse a harmonizing influence wherever the sun shines, and unite all together without distinction. They strike their watch-wood ${ }^{14}$, and at its sound

1 A semi-Buddhistic name = 'spirits-devas.'

${ }^{2}$ Evidently Tâ Ts'in is here used for Judea, or at any rate Judea was considered by the writer to be a part of Tâ Ts'in.

${ }^{3}$ Most probably the writers of the Books of the Old Testament; see Renaudot, in his 'Anciennes Relations des Indes et de la Chine,' p. 244.

' A reference to the commencing chapter of 'The Great Learning.'

${ }^{5}$ Compare a similar expression in the Tâo Teh King, ch. 2.

' Bridgman has here, ' $\mathrm{He}$ established the measure of the eight boundaries;' and to the same effect, Wylie. A Christian Chinese suggested to Bridgman a reference to 'the eight Beatitudes.'

7 Probably, the three graces of 'Faith, Hope, and Love.'

${ }^{8}$ The vessel of mercy or salvation appears again in the Inscription.

${ }^{9} \mathrm{~A}$ reference to the 6 rd hexagram of the Yî King.

10 The Books of our New Testament.

11 Tâoistic phraseology.

12 Evidently the writer here passes from the work of Christ to that of His ministers, and we must make a new paragraph.

13 The character for ten (†) stands here for the sign or figure of the 'Cross.'

14 Every one who has passed a night in a Chinese monastery knows what the striking of the wood is. 


\section{八碑國中行流教景}

文道 蔍齋 所擊

皇非洗以以林

帝，聖心伏 無 震

光不反識内仡

華 弘、素。而 情、惠

啟 聖 $\bigcirc$ 成, 不之

運, 非異戒音音。

明道常以臓東

聖 不之 静 獲、禮

臨大, 道, 稘均趣

人、道 妙爲貴 生

大 聖 而 固、賤 榮

秦符 難 七於之

國契，名時人、路。

有 天 功禮 不 存

上下用讚、聚 鬚

德交昭大貨所

日明。章、庇財、以

阿 $\bigcirc$ 强存 $\bar{\pi}$ 有

羅被 亡。馨 外

本。景七 遗行。

占太教。日 於詷

靑宗惟一我, 頂 
Objects and

Ways of the

Communities.

are stimulated to love and kindness. They turn ceremoniously to the east, and hasten on in the path to life and glory. They preserve their beards to show how their work lies without themselves; they shave their crowns to show that they have no inward affections of their own ${ }^{1}$. They do not keep or maltreat slaves, male or female ${ }^{2}$. They make no distinction between noble and mean among men. They do not accumulate property or wealth, but give all they have to our (communities). They fast to subdue (the pride of) knowledge and become perfect ; they keep the vigil of stillness and watchfulness to maintain (their minds) firm. Seven times a day they have worship and praise for the great protection of the living and the dead ${ }^{3}$. Once in every seven days they have a public service ${ }^{4}$, cleansing their hearts and regaining their purity.

6. This true and unchanging system of doctrine is mysterious

The name

'Illustrious

Religion.' and difficult to name. To display its manifest operation, we make an effort and call it the Illustrious Religion ${ }^{5}$.

But any (such) system without (the fostering of) the sage ${ }^{6}$ (sovereign) does not attain its full development, and a sage (sovereign) Co-operation of without the aid of such a system does not become the Sovereign. great. Let the sage (sovereign) and the (right) system come together like the two halves of a seal or covenant, and the world will become polished and enlightened.

II. 7. When the Accomplished Emperor T'âi Tsung (A. D. 627-649) commenced his glorious reign over the (recently) established dynasty (of $\left.\mathrm{T}^{\text {'ang }}\right)^{7}$, presiding over men with intelligence and sagehood, in the kingdom of $\mathrm{Ta} \mathrm{Ts}^{\text {cin }}$ there was a man of the highest virtue called Olopun ${ }^{8}$. Guiding himself by the azure clouds, he carried with

1 This symbolism of the beard and shaven crown is curious.

${ }^{2}$ See the K'ang-hsî dictionary, under 步㦴,

${ }^{3}$ That their services were supposed to benefit the dead as well as the living appears elsewhere. Visdelou calls attention to this feature in the Inscription.

${ }^{4}$ No doubt, celebrated the communion.

${ }^{5}$ Compare the language of the Tâo Teh $\mathrm{King}$ in ch. $\mathbf{1}_{5}$, and especially in ch. ${ }^{25}$, on the latter of which that of the Inscription here is moulded. As Lâotsze 'makes an effort,' and calls his system 'the Great Tâo,' so the writer calls his 'the Illustrious Teaching (or Doctrine).' 'Illustrious' in the Inscription is equivalent to Christian.

${ }^{6}$ So, again, in the Tâo Teh King, Shăng (聖), however we translate it, often stands for the sovereign.

7 T'âi Tsung was not the founder of the T'ang dynasty, as Wylie's and other translations unnecessarily say. His father Kâo Tsû was the first emperor in 624 .

${ }^{8}$ Olopun is a Syriac name. The Olo is equivalent to $\mathrm{El}$ in many Hebrew 


\section{十碑國中行流教景}

說 來 無 知 宰 雲

理 獻 常 正臣而

有上體, 椇, 房載

忘京, 隨 特公真

鉒、祥方令立 經。

濟 其 設 傳 齡、望

物 教 教、授。忽 風

利旨、密 貞 仗 律

人、立濟 觀 西 以

宜妙薜十郊。彁

行 無 生, 有 筫 芣

天爲大二迎險

下。觀 秦 年 入 貞

其 國秋 內, 觀

所元大七翻九

司宗, 德月。經 祀。

即生 阿 詔書 至

於成羅 日、殿、於

京立 本, 道 問 長

義要, 遠無道 安。

耑詞將 常 禁

坊、無 經 名、闈、帝

造 繁 像。聖 深 使 
Arrival of

Olopun at the Chinese capital, and favourable reception by the emperor Tैâi Tsung.

him the True Scriptures. Watching the laws of the winds, he made his way through difficulties and perils. In the ninth year of the period Chang-kwan (A.D. 635), he arrived at Ch'ang-ân. The emperor sent his minister, duke Fang Hsüan-ling ${ }^{1}$, bearing the staff of office, to the western suburb, there to receive the visitor, and conduct him to the palace. The Scriptures were translated in the Library ${ }^{2}$. (His Majesty) questioned him about his system in his own forbidden apartments, became deeply convinced of its correctness and truth, and gave special orders for its propagation. In the twelfth Chăng-kwan year $\left(63_{3} 8\right)$, in autumn, in the seventh month, the following proclamation was issued:-'Systems have not always the same name; sages have not always the same personality. Every region has its appropriate doctrines, which by their imperceptible influence benefit the inhabitants. The greatly virtuous Olopun of the kingdom of Tâ $\mathrm{Ts}^{\prime}$ in, bringing his scriptures and images ${ }^{3}$ from afar, has come and presented them at our High Capital. Having carefully examined the scope of his doctrines, we find them to be mysterious, admirable, and requiring nothing (special) to be done; having looked at the principal and most honoured points in them, they are intended for the establishment of what is most important. Their language is free from troublesome verbosity; their principles remain when the immediate occasion for their delivery is forgotten ${ }^{4}$; (the system) is helpful to (all) creatures, and profitable for men:-let it have free course throughout the empire ${ }^{5}$ ?'

8. The proper officers forthwith, in the capital in the Ward of Righteousness and Repose ${ }^{6}$, built a Tâ Ts'in monastery ${ }^{7}$, sufficient

names. 'The Greatly Virtuous' is perhaps not more than the equivalent of our 'Reverend,' or 'Father.' It will be found elsewhere.

${ }^{1}$ See the memoir of this minister in the 2 1st chapter of the Biographies of T'ang (列 傳), and also a reference to him, with the title which he bears here, in the first Book of the Piâo (表) (i. p. $2^{\mathrm{a}}$ ).

${ }^{2}$ This can only mean that portions of the Scriptures were translated.

${ }^{3}$ So Fâ-hien went home from India; see his Travels, p. II5, et al. I suppose the images here would be crucifixes.

4 M. Pauthier tried to give this clause more literally:-'Les principes en subsisteront encore lorsque les filets qui auront servi à la pêche seront oubliés.' The writer evidently had in his mind an expression of Chwang-tsze, near the end of his 26 th Book (外物). The meaning seems to be what I have given.

${ }^{5}$ Here I think the words of the proclamation should terminate.

'The subdivisions of Peking are called 'wards' as here, and we know, from a work of the Sung dynasty, that there was a 'Ward of Righteousness and Repose' in Ch'ang-ân.

7 Not 'a church;' one of its halls would serve the part of one. Compare 


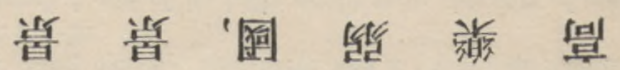

学睅沺

具 竎 $\gamma$ 臂 $V$

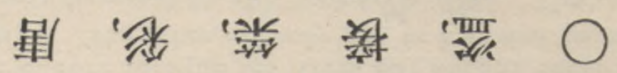

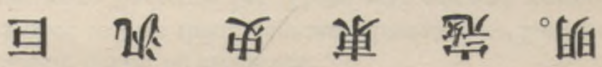

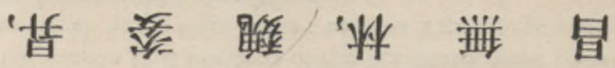

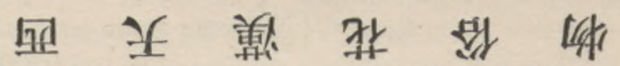

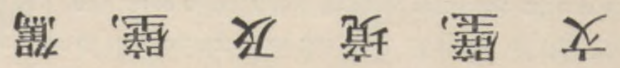

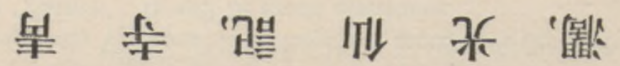

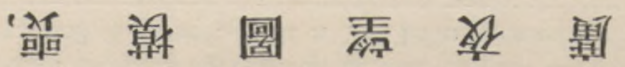

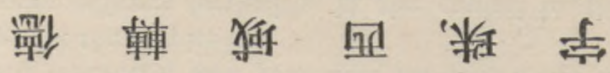

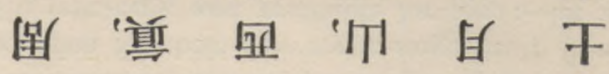

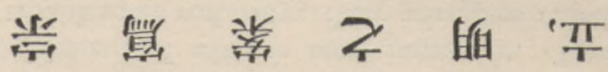

'

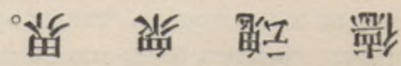

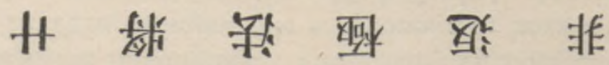

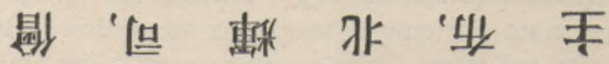

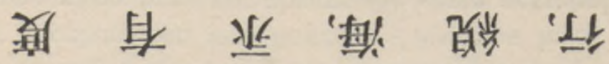

等

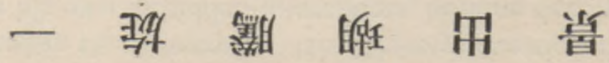

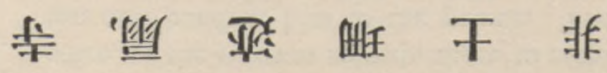

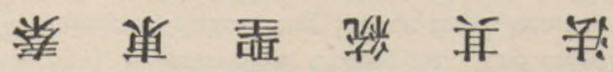

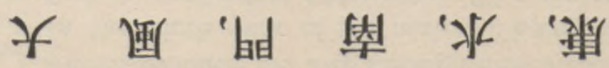

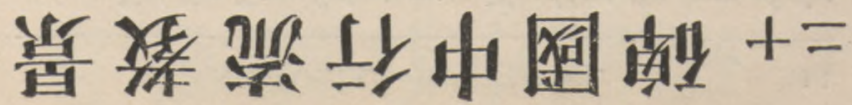


to accommodate twenty-one priests. The virtue of the

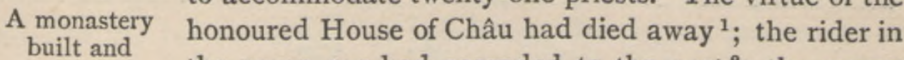
adorned. the green car had ascended to the west ${ }^{2}$; the course of the great T'ang was (now) brilliant; and the breath of the Illustrious (Religion) came eastward to fan it. The proper officers were further ordered to take a faithful likeness of the emperor, and have it copied on the walls of the monastery. The celestial beauty appeared in its many brilliant colours, the commanding form irradiated the Illustrious portals; the sacred traces communicated a felicitous influence, for ever illuminating the precincts of the (true) Law.

9. According to the Illustrated Record of the Western Regions, and the histories of the Han and Wei dynasties, the kingdom of Tâ Ts'in commences at the south with the Coral Sea, The country of and reaches on the north to the mountain of all PreTâ Ts'in.

cious Things; on the west it looks towards the flowery forests on the Borders of the Immortals, and on the east it lies open to the long winds, and the weak water. The country produces the asbestos cloth, the soul-restoring incense, the bright-moon pearls, and the night-shining gems. Robberies and thefts are unknown among the common people. Men enjoy happiness and peace. None but the Illustrious Religion is observed; none but virtuous rulers are appointed. The territory is of vast extent; its literary productions are brilliant $^{3}$.

the account of the first reception of the Buddhist monks from India in our first century, as referred to in the Lecture. It appears also that Olopun must have arrived with a large company, or had arranged with the Emperor to send to Tâ Ts'in for such.

1 'The honoured (Capital or House) of Chân' is a frequent expression in the Shû King for the dynasty of that name (see V. xviii. I, et al.) ; I must think that the writer was thinking of it as having been made what it was by the duke of Châu and by Confucius.

2 'The rider in the green car' must be Lâo-tsze, who was reported to have disappeared from the country in such a vehicle. The clanse about him is coordinate with the former. The two, and the clause that follows, augur more for the $T^{*}$ ang dynasty from the Illustrious or Christian religion than former ages had obtained through Confucianism and Tâoism.

${ }^{3}$ I could wish that this paragraph about Tâ Ts'in had not been in the Inscription, and it is difficult to perceive the object which it serves. The Record to which it refers must be lost, but the Han and Wei Histories remain. For an able and exhaustive treatment of all the accounts of Tâ Ts'in in the Chinese Records, see Dr. F. Hirth's 'China and the Roman Orient' (Shanghâi and Leipsic, $\mathrm{I}^{88_{5}}$ ). The southern boundary here assigned to the country may be the Red Sea, and the northern the mountain ranges lying far north; but of the other boundaries I have no idea, 'Asbestos cloth' is indicated by three characters, of which the second is unexampled in that meaning; though such cloth, 


\section{四十碑國中行流教景}

$\bigcirc$ 本 宗

聖 爲大

歴 鐄 帝。

年、國 克

釋 大 恭

子 法 絓

用主。祖。

壯、法 潤

騰流色

口十产

於道、宗

東國而

周。富 於

先 元 諸

天 休、州

末 寺 各

下 滿 置

士 百 景

大城，寺。

笑 家 仍

訕殷 崇

謗 景 阿

於 福。羅 
10. The great emperor Kâo Tsung (650-683) reverently continued (the line of) his ancestors. A beneficent and elegant patron of the Prosperity under Truth ${ }^{1}$, he caused monasteries of the Illustrious (ReKâo Tsung. ligion) to be erected in every one of the Prefectures, and continued the favour (of his father) to Olopun, raising him to be Lord of the Great Law, for the preservation of the state. The Religion spread through the Ten Circuits ${ }^{2}$. The kingdoms became rich and enjoyed great repose. Monasteries filled a hundred cities; the (great) families multiplied in the possession of brilliant happiness ${ }^{3}$.

II. In the period Shăng-lî $(698,699)^{4}$, the Buddhists, taking advantage of their strength, made their voices heard (against the Religion) in the eastern capital of Châu, and in the end of the year Hsien-tien ${ }^{5}$

no doubt, is intended. The character translated 'robberies' has never been previously identified. In Kircher's transcription it is 侵, and even Hirth gives 祅灵, which is not found in the dictionaries; he can hardly be intending 禅. But let any student refer to 補, 'a cap,' in the K'ang-hsî dictionary under $\mapsto$ with seven strokes, and then refer to the form of it which is the last character in the same category, and I think he will not hesitate to conclude that the character in the inscription is a disused form of 莩, 'a robber,' which I have given.

${ }^{1}$ Compare the phraseology in Confucian Analects, 14. 9.

${ }^{2}$ In his first year $(627)$ T'âi Tsung had divided the empire into ten Tâo (道), which I have called 'Circuits.' They were really the 'provinces' of the empire, and were afterwards increased to fifteen. The use of the term here is a strong confirmation of the genuineness of the monument.

3 Kâo Tsung's reign was a period of great prosperity for the new Religion.

4 The Inscription thus passes from 683 to 698 , without intimating, by its usual method of leaving two vacant spaces, that a new succession to the throne had taken place. There was a period of great disorder in the empire from $68_{3}$ to 7r3. Kâo Tsung's son, known as Chung (中), succeeded to him, but the empress-dowager Wû (武 民) displaced him, and appointed another son, known as Jui (歪) Tsung, in his place: at the same time she kept the reins of government in her own hands till $7 \circ 5$, changing among other things the name of the dynasty from T'ang to Châu. Hence we have, in this paragraph, the city of Lo appearing as the eastern capital of Châu, and Ch'ang-ân named 'the western Hâo,' the capital of King Wû of the ancient Chân, B. C. II 22. Amid the troubles of the time and under the empress Wû, who had herself once been the inmate of a nunnery, the Buddhists found an opportunity of endeavouring to check the progress of the Illustrious Religion.

${ }^{5}$ In 705 Chung Tsung regained the throne, but was murdered in 710 , when Jui Tsung succeeded to him. He, however, resigned the throne in $76_{2}$ to his 


\section{六十碑國中行流教景}

慶 令 福 立 西

点大宇、綱、鎬、

圖、將 建 俱 有

龍 望 立維 若

䰉 高 壇 絶 僧

雖力塲、紐。首

遠士。法 $\bigcirc$ 羅

弓送棟 含。

劍 暫 大

可橈 立 德

攀、五而宗及

日 聖更至 烈

角寫崇, 道 前

舒 真 道 皇 金

光、寺 石 帝，方

天 內 時 令 貴

顔安傾塪 緒。

迟 置 而 國 物

尺。賜 復 等 外

三 絹 正。五 高

載，百 天 王。僧

大 正、寶 親 共

秦 奉 初, 臨 振 
Reverses under (712), some inferior officers greatly derided it; slanthe next reign. dering and speaking against it in the Western Hâo. But there were the chief priest Lo-han, the greatly virtuous Chî-lieh and others, noble men from the golden regions ${ }^{1}$, all eminent priests, keeping themselves aloof from worldly influences, who joined together in restoring the mysterious net ${ }^{2}$, and in rebinding its meshes which had been broken.

12. Hsüan Tsung (713-755), the emperor of the Perfect Way, ordered the king of $\mathrm{Ning}^{3}$ and the four other kings with him to Restorations of go in person to the blessed buildings, and rebuild their Hsiian Tsung. altars. The consecrated beams which had for a time been torn from their places were (thus) again raised up, and the sacred stones which had for a time been thrown down were again replaced.

In the beginning of the period T"ien-pâo (742-755), orders were given to the great general Kâo Li-sze ${ }^{4}$, to send faithful likenesses of the five sacred (emperors) ${ }^{5}$, and have them placed securely in the (originai) monastery, with a gift of a hundred pieces

Special marks of silk. The elegant pictures were presented with (the of favour, and proper) congratulations. Although the dragon (i.e.

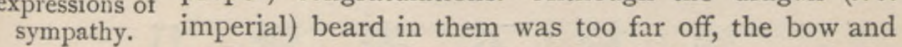
sword could be touched with the hand; when the sun's horns (= rays) shed on them their light, the celestial countenances seemed to be within about a cubit (from the spectator).

own son; and that year has two names,- those of T'âi-chî, as the last year of Jui

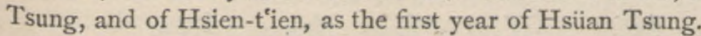

1 Who these men from the golden regions might be we cannot tell. Any region west of China might be thus described. See the K'ang-hsî Thesaurus, under the name 金序.

${ }^{2}$ I cannot tell whether the character in the Inscription here be equivalent to wang (縘) 'a net,' or kang (絧) 'the great rope of a net;' whichever it be, the writer was thinking of the Illustrious Religion as a net that had been damaged.

3 The king of Ning was the elder brother of the emperor Hsiian, who declined to be nominated heir-apparent in 710 , being then king of Sung. The emperor made him king of $\mathrm{Ning}$ in $7 \mathrm{Ig}$. The other four kings were all brothers of the two, and the emperor built a common residence or palace for them, to which there is reference in a subsequent paragraph.

4 'Though 'a great general,' Kâo Lî-sze might well be charged with this commission, for he was a eunuch, employed about the palace since the time of the empress Wû ; but at the same time of more than ordinary ability and strength. See his interesting history in the 132 nd chapter of the Biographies of the T"ang History. He was made 'Great General of the Cavalry' in $74^{8}$, and is so styled in the Inscription $e x$ post facto.

Probably Hsiian Tsung, and his predecessors. 


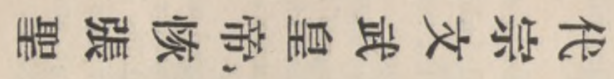

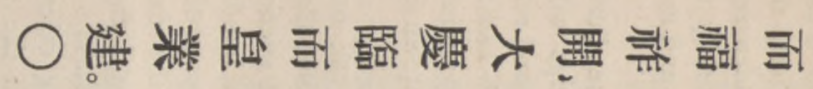

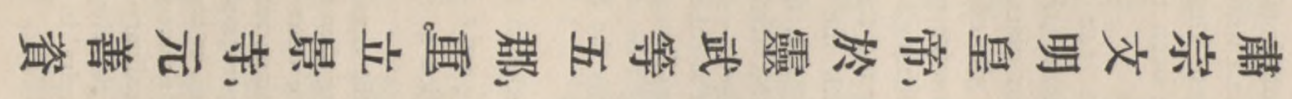

○蘚

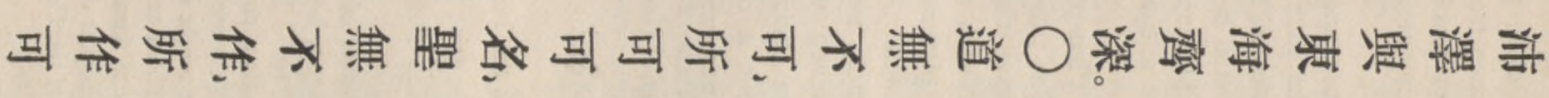

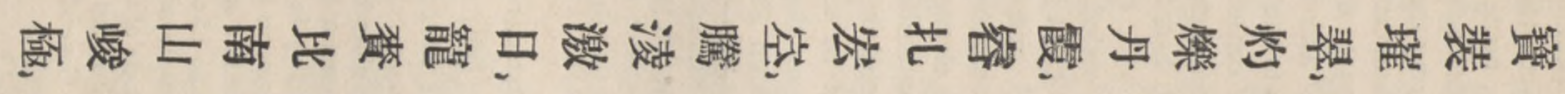

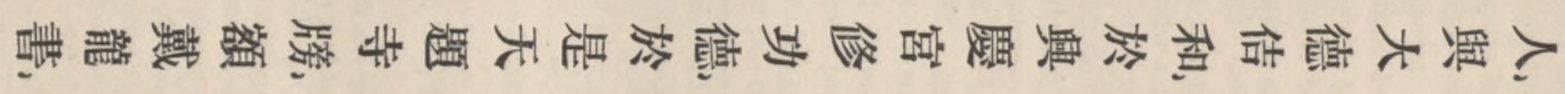

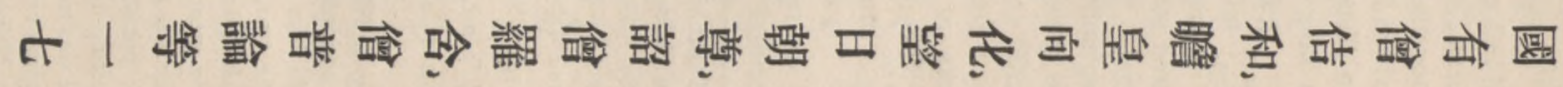


In the third year of the same period (744), in the kingdom of Tâ Ts in there was the monk Chî-ho. Observing the stars, he directed his steps to (the region of) transformation ${ }^{1}$; looking to the sun, he came to pay court to the most Honourable (emperor). An imperial proclamation was issued for the priests Lo-han, $\mathrm{P}^{\prime} \hat{\mathrm{u}}$-lun and others, seventeen in all ${ }^{2}$, along with this greatly virtuous Chî-ho, to perform a service of merit in the Hsing-ch'ing palace ${ }^{3}$. On this the celestial inscriptions appeared on the walls of the monastery, and its lofty front bore the dragon-writing. The precious lines were like the shining feathers of the king-fisher, and splendid as the ruby hues of the clouds about the sun. The tablets of wisdom filled each empty space, and their radiance rose up as if to provoke the sun. The gifts of favour were immense as the vast height of the southern hill ; and the flood of rich benevolence like the depth of the eastern sea.

13. There is nothing which the right principle cannot effect, and whatever it effects can be named. There is nothing which a sage (sovereign) cannot do, and whatever he does can be related.

14. The emperor Sû Tsung (756-762), Accomplished and Intelligent, rebuilt the monasteries of the Illustrious (religion) in

Further progress.

Ling-w $\hat{u}^{4}$ and four other parts. His great goodness (continued to) assist it, and all happy influences were opened up ; great felicity descended, and the imperial inheritance was strengthened.

15. The emperor Tâi Tsung (763-779), Accomplished and Martial, Favours and grandly signalized his succession to the throne, and patronage of conducted his affairs without (apparent) effort. Always Tâi Tsung. when the day of his birth recurred ${ }^{5}$, he contributed

${ }^{1}$ Chî-ho, no doubt, came from Tâ Ts'in with a reinforcement of labourers for the work of the Mission, encouraged by the news of its success which had been carried to the west. The Chinese character employed for 'year' in the previous sentence is a remarkable proof that the Inscription is genuine. The character 年 was changed in that year to the 載 which we have.

2 'Seventeen,' I think, and not merely seven.

3 The service would be one of thanksgiving and prayer.

4 The part of Ling-wû corresponded to the present Ling Châu in the prefecture of Ning-hsiâ in Kan-sû. In the earlier reigns of the T'ang dynasty, it was called Ling Châu, but early in the T'ien-pâo period that name was changed into Ling-wû Chün, the very name used here.

5 Was this the birthday of the emperor? or the day of the birth of the Messiah? Wylie adopts the latter view, as does Huc. There is no doubt the other view is the correct one. We read in Nien Ch'ang's History of Buddhism (佛祖歴代通載, xiv. p. 18) that Tâi Tsung on his birthday (the same phraseology as in the text) had a service performed for him also by a large company of Buddhist monks! 


\section{十二碑國中行流教景}

誠 時, 苦、命、建 景 運。

者。天善化中蟌。從

我下貸通聖且事

景静、被立神乾無

力人集理, 交以爲

能 能 生 祝 武 美 每

事理、者、無 皇利、於

之. 物我愧帝, 故 降

功能修心披能誕

用清。行至八廣之

也。存之於政生、唇、

○能大方以.聖錫

大昌, 鄭。大黠以天

施沿汲而陟體香

主能引虛。幽元以

金 樂, 之 專 明。故 告

紫 念階 静闡 能成

光生濑而九亭功。

祿 響 也。恕疇 毒。頒

大 應, 若廣以 $\bigcirc$ 御

夫, 情 便慈惟饌

同發風救新以

朔目雨蟌景我光 
celestial incense wherewith to announce the meritorious deeds accomplished by him, and sent provisions from his own table to brighten our Illustrious assembly. As Heaven by its beautiful ministration of what is profitable can widen (the term and enjoyment of) life, so the sage (sovereign) by his embodiment of the way of Heaven, completes and nourishes (the objects of his favour) ${ }^{1}$.

I6. In this period of Chien-chung ( $780-783)$, our present emperor ${ }^{2}$, Sage and Spirit-like, Accomplished alike for peace and war, developes the eight objects of government ${ }^{3}$, so as to degrade the undeserving, and promote the deserving ${ }^{4}$; and exhibits the nine The virtues of divisions of the scheme (of Royal government) ${ }^{5}$, to Teh Tsung, and impart a new vigour to the throne to which he has the influence of Christianity

on him.

illustriously succeeded. His transforming influence shows a comprehension of the most mysterious principles; (his) prayers ${ }^{6}$ give no occasion for shame in the heart. In his grand position he yet is humble; maintaining an entire stillness, he yet is observant of the altruistic rule. That with unrestricted gentleness he seeks to relieve the sufferings of all, and that blessings reach from him to all that have life is due to the plans of our (Illustrious Religion) for the cultivation of the conduct, and the gradual steps by which it leads men on. That the winds and rains come at their proper seasons ; quiet prevail through the empire ; men be amenable to reason; all things be pure; those who are being preserved flourish, and those who are ready to die have joy; every thought have its echo of response ; and the feelings go forth in entire sincerity :-all this is the meritorious effect of its Illustrious power and operation.

17. A great benefactor to us is the priest 1 -sze ${ }^{7}$, a great officer of

1 Evidently a quotation, in the last two characters, from the Tâo Teh King, ch. 51. Failing to perceive this, most of the translators have missed the meaning.

${ }^{2}$ This was Teh (德) Tsung, but he would not be so designated till after his death.

${ }^{3}$ See the Shû, V. iv. 7 .

${ }^{4}$ Quoted from the Shû, II. i. $27 . \quad{ }^{5}$ See the Sht̂, V. iv. 3.

- This may possibly mean 'our prayers for him.'

7 This I-sze had come, we are told, 'from afar, from the city of the Royal dwelling,' which was a name for the residence of the Magadha kings from Bimbisâra to Aśoka, - the first metropolis of Buddhism. See the Travels of Fâ-hien, p. $8 \mathrm{r}$, n. 5. He had come thence to China, which is here called 'The Middle Hsiâ,' a synonym of 'The Middle Kingdom,' on the title of the Inscription; see instances of such use of the name in the K'ang-hsî Thesaurus, under Hsiâ (夏). We may conclude, therefore, that in the preceding reign of Sû Tsung he had arrived as a Buddhist monk, and by his great qualities had risen to distinction in the service of the government. On the robes conferred on him as a minister, see the K'ang-hsî Thesaurus, under 紫. (金督 and 賜 紫). 


\section{二\#碑國中行流教景}

鲛爲傽丹行, 方 㦝公方庭, 遠 節 之爪也、乃自度 金 牙、䇠 王 副 羂作名舍 使。 或軍肅於之試 仍耳宗王城。殿 其目。俾帳、聿中 舊能之中來監 寺, 散、從書 中 賜 或禄邁、令。夏、紫 重賜 雖汾術袈 廣不見陽高裟。 法 積 親 䛨三僧 堂、於於王。代，伊 崇 家、卧 郭 藝 斯。 飾 獻内、公博 和 廊 臨不子十而 宇、恩自儀，全，好 如之異初始惠 翬 頗 於菢効 聞 斯 黎, 行 戎 節 道 飛布閒。於於 勤 
the Banqueting Court, wearing the robe of purple wrought with gold, bearing also the seal of Associate Commissioner for Of the virtues the Northern Regions, and, as overseer of the Exam-

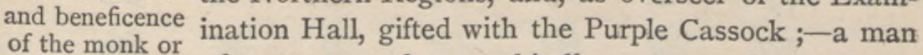
of the monk or of courtesy and most kindly nature, who zealously
priest I-sze. carries into practice the (right) way when he hears it. From afar, from the city of Râjagriha, he came to Chung-hsiâ (i.e. to China). His science surpassed that of the three dynasties, and his arts were extensive and in all respects complete. Performing at first certain duties in the palace ${ }^{1}$, his name came to be entered in the pavilion ${ }^{2}$ of the kings. When the duke Ko Tsze- $\hat{\imath}^{3}$, a secretary of state, and king of the division of Fun-yang, was first appointed to the charge of the military operations in the northern regions, (the emperor) Sû Tsung gave him this (î-sze) to accompany him to his command. Though he enjoyed (the duke's) favour in his sleepingtent, he made no difference between himself and others on the march. He was claws and teeth to the duke, and was ears and eyes to the army. $\mathrm{He}$ distributed his emoluments and presents, accumulating nothing in his own house. He made offerings (to the Illustrious Communities) of the glittering ornaments which he received as gifts ${ }^{4}$; he spread out (in their halls) the carpets interwoven with gold as resting-places for the speakers; in some he repaired the old monasteries as they had been before ; in others, he enlarged the preaching-halls, elevating and ornamenting their corridors and walls, till they appeared like pheasants

Arrived in China, we may almost conclude that he became a Christian, and threw all his influence into the scale of 'The Illustrious Religion.' This conclusion I would draw from the statement that 'when he heard the right way, he zealously practised it;' compare the Analects, IV. 8, V. r3. As Associate Commissioner for the Northern Regions he would have his seat at Ling-wâ, mentioned in paragraph $\mathbf{1} 4$.

I Literally, 'the Red Court;' a name, according to Dr. Williams, for 'the imperial palace, especially the private apartments.' We want more information about it.

${ }^{2}$ And we want the same about this expression. In the K'ang-hsî Thesaurus we have a reference to 'the pavilion of the five kings,' the same expression as here, with the addition of 'five,' as from a Book of the T'ang dynasty. Of the residence of the five kings mention has been made in a note on par. I3. I suppose that a register was kept there of the officers about the court and their suitability for higher employments; and that among these $\hat{\mathrm{I}}$-sze was now registered.

3 The 6 and of the Biographies of the Books of $T^{\prime}$ ang gives the history of this minister at great length, one of the ablest of the commanders of the dynasty. His offices and dignities are all mentioned as here, and especially his operations as protector of the northern regions. He died in 782 , the year after the erection of our Monument, at the advanced age of $8_{5}$.

${ }^{4}$ Literally, ' articles of glass,' including, I suppose, all that we call objets de vertu. 


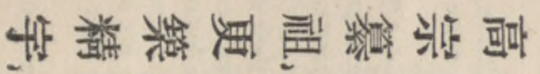

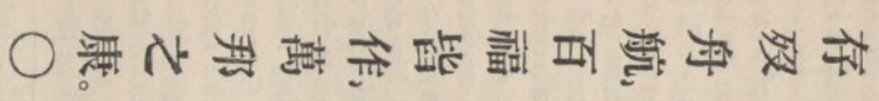

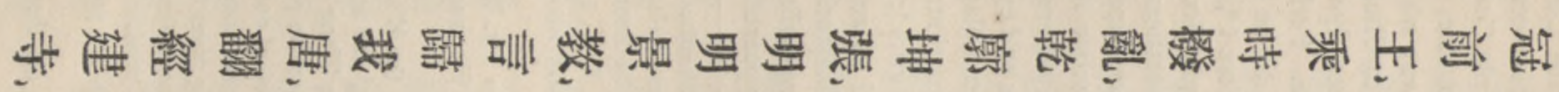

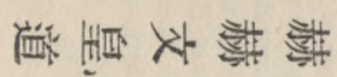

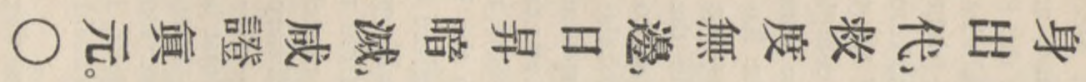

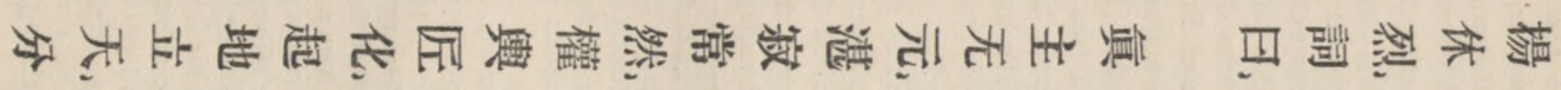

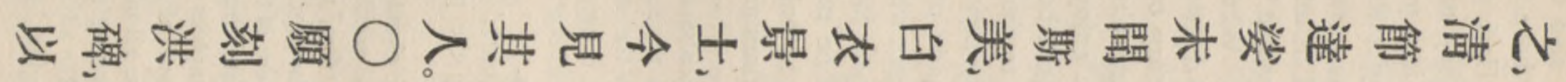

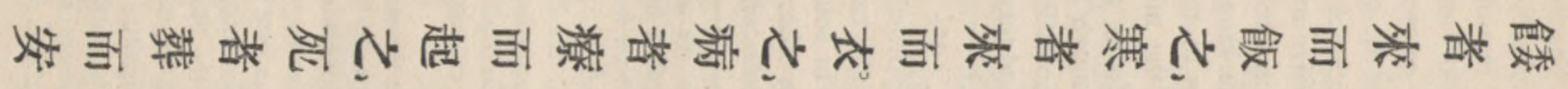

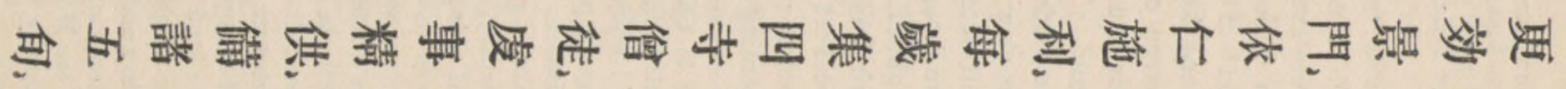

$\neq$

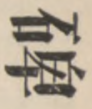

四

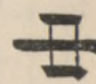

긴

ㅊำ

tits

기멤 
on the wing ${ }^{1}$. Carrying out further the rules of the Illustrious Religion, he expended his acquisitions in deeds of benevolence. Every year he assembles the priests of all the monasteries ${ }^{2}$, who engage in their reverent services and pure offerings for all the space of fifty days. The hungry come and are fed; the cold come and are clothed; the sick are cured and restored to health ; the dead are buried and laid to rest in their graves.

Among the purest and most self-denying Buddhists ${ }^{3}$, such excellence was never heard of; but now the white-stoled members of the Illustrious Religion see it in this man.

III. 18. Wishing to engrave on a great monumental pillar our sense of the eminent and meritorious (events which we have related), we enter on it our eulogy as follows :-

[i] $\mathrm{He}$, the true Lord, Himself uncaused, Profound and still, is aye the same.

The universe His handiwork,

Earth rose and heaven received its frame.

His separate Godhead ${ }^{4}$ men then saw ;

His saving work no limits knew.

The sun arose, the darkness fled,

And all approved the mystery true.

[ii] The Accomplished Sovereign gloriously

Showed the old kings by him surpassed.

His car o'er all disorder rode;

Heaven grew more wide, and earth more vast.

Our brightest Truth then came to T'ang;

Its Scriptures spoke in T'ang's own tongue;

Its monasteries in grandeur rose;

To save both quick and dead forth sprung

Its ship. All blessings straight arose ;

The myriad regions had repose.

[iii] Kâo Tsung succeeded to his sires, And built the dwellings Pure anew. Those palaces resplendent stood, Harmonious homes, the empire through.

1 A line quoted from the Shih King, II. iv. ode V. 4.

2 'Four monasteries,' or 'the monasteries of the four quarters.'

3 'Buddhists' is expressed here by 達 婆 $=$ dha-sa, which Pauthier thinks is the transcription of the Sanskrit term daśarhas, 'a Buddhist,' and refers to Wilson's dictionary sub voc. But Wilson's meaning is 'a Buddha.'

1 See note 7 on par. 4 . 


\section{六井碑國中行流教景}

報 區駕、䖤、苦。和 功、夏。聖率 $\bigcirc$ 宮 化 日 日 敞 以舒高朗。 作晶，敬、立遍 施、代祥庶宗滿 暘宗風績啟中 谷孝掃咸聖土土 來 義、夜、熙 克 巅 威。德祚人修道 月合歸 頼䢐宣 窟天皇其正, 明。 畢 地, 室, 慶。御 式 萃。開积 $\bigcirc$ 牓 封 貸氛 揚 法 生承輝, 主。 成、謝、肅天人 建 物 止宗書 有 中資沸來蔚 樂 統 美 定 復、映、康、 極、利、塵、天 皇 物 聿 香 造 威 圖 無 修以我引墔、災 
The way of Truth was clearly preached, And one was made Lord of the Law. Men joyful owned its blessed peace; The land nor pain nor sorrow saw.

[iv] Hsüan Tsung his sacred course began; His mind pursued the Truth and Right. His notices adorned our walls ; His heavenly lines gave forth their light.

Pictures he sent like pendent gems;

And reverence ruled throughout the land.

All services were well discharged ${ }^{1}$;

Men hailed our Law a blessing grand.

[v] Sû Tsung's benignant reign then came $^{2}$;

Majestic did his car appear.

His sacred sun a crystal disk,

Auspicious winds the night swept clear.

The imperial House again was blessed;

The stifling ${ }^{3}$ yapours died away.

Passions were stilled and tumults checked;

Our Middle Hsiâ renewed its day ${ }^{4}$.

[vi] Tâi Tsung was Filial and Just,

Both heaven and earth were in him found.

The open hand, by nature his,

Dispensed his succours all around.

Incense his merits told to Heaven;

Benevolence aye marked his name.

From the sun's rise men owned his might;

From the moon's caves in crowds they came.

1 This line is taken from the $\mathrm{Sh} \hat{\mathrm{u}}, \mathrm{I}$. p. 8.

2 The last two characters of this line are from the Yî King, Hex. 24 .

${ }^{3}$ The character in the Inscription here has always been mistaken. It is 枖, the $\mathcal{F}$ on the right being made irregularly, as may be seen in the concluding note on $\mathcal{X}$ in the $\mathrm{K}^{\prime}$ ang-hsî dictionary. Bridgman read it $X_{\mathcal{K}}$, or accepted it as such from Kircher, and Wylie must also have taken it so, as we see from the

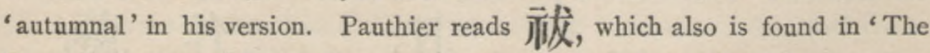
Great Collection of Inscriptions on Metal and Stone,' of which I have spoken in the Lecture. When now we turn to 䄶 in the K'ang-hsî, we are referred for the meaning of the character to 解 = 'surfeiting,' 'stifling.'

${ }^{4}$ An application, not very clear, of the conclusion of the first chapter in the Sh $\hat{u}, \mathrm{~V}$, ix. 


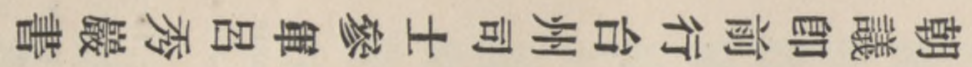

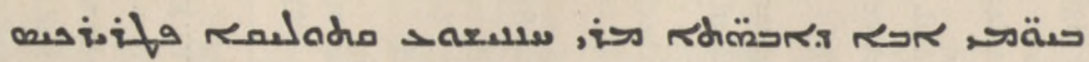

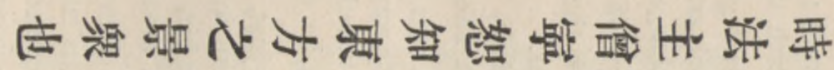

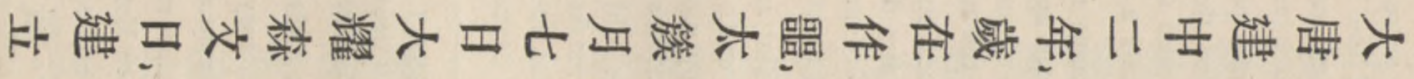

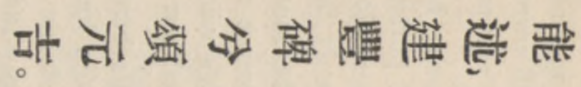

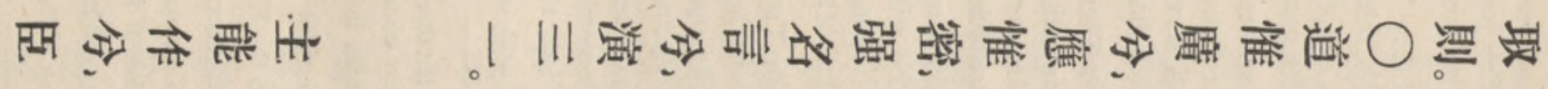

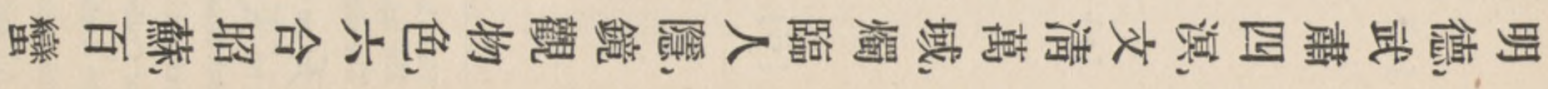


[vii] Our emperor of the present time, Has widest sway and virtue bright. Within the seas all own his power; The myriad regions hail his light.

No secrets from his view concealed, His mirror all things well describes. The world from him gets life and light, A pattern to the rudest tribes.

[viii] How vast ${ }^{1}$ the system of our faith !

Its answers come how secretly!

'Tis hard for us to form a name, To indicate our Trinity.

Their lord can act; his ministers

Can but relate. This stone we raise.

Our monument we rear thus vast, And, greatly blessed, we bless and praise.

Erected in the second year of the period Chien-chung (A. D. 78I) of the great T'ang dynasty, the year-star being in Tso-yo ${ }^{2}$, on the seventh day of the first month ${ }^{3}$, being Sunday ${ }^{4}$.

The present Chief of our Law being the priest Ning-shû, charged with the care of the Illustrious Communities of the East.

(In Syriac.) In the days of the Father of Fathers, my lord HananYeshu', Katholikos, Patriarch ${ }^{5}$.

(In Chinese.) Written out by Lü Hsiû-yen, Secretary of State, formerly discharging the duties of military superintendent in T'âi-châu.

1 The inscription has here $\frac{\text { 贯. }}{3}$.

${ }^{2}$ A peculiar Cyclical nomenclature, intimating that the year was one of the five yu (西) years of the Cycle; in this case Hsin-yû (=A. D. $78 \mathrm{I}$ ).

3 The inscription has here $\boldsymbol{H}$ instead of $\boldsymbol{M}$.

4 The characters 大䊒森文 日 would seem to be intended, not only to say that the day was a festival day, but also what festival it was.

${ }^{5}$ This is an important note of time, and occasions some little difficulty. We know from the Bibliotheca Orientalis Clementino Vaticana of J. S. Assemani that this Hanan-Yeshn' was created Patriarch of the Nestorians at Bagdad in 774 , and died in $77^{8}$; whereas here is this monument erected in 781. But is not this discrepancy rather a proof of its genuineness? The news of the patriarch's death had not reached them at Ch'ang-ân. In fact, according to Assemani (vol. iii. I, 347), the canon for communication between the more distant metropolitan sees and the patriarchate required the interchange of messages only once in six years. 


\section{十三碑國中行流教景}

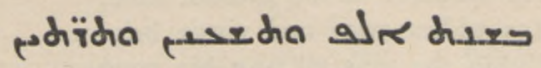

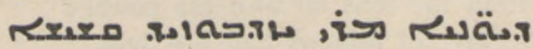

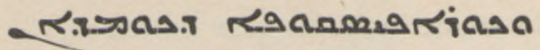

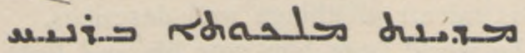
T.

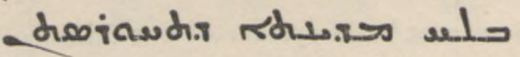

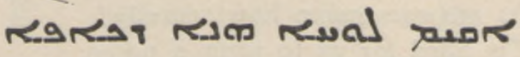

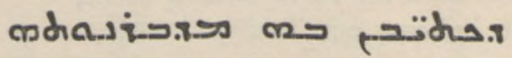
andolnisa مoniax

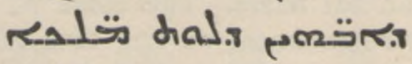

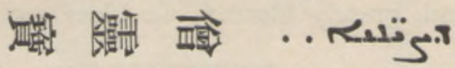
iv rexprs

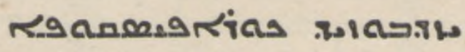
Terestivis .. Ranacesariasa

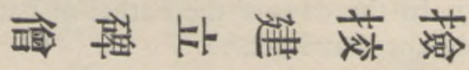

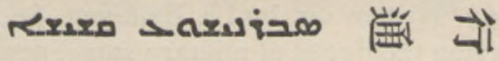

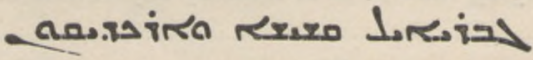

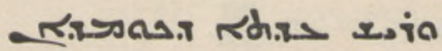
$\rightarrow$ iora

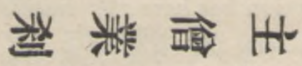

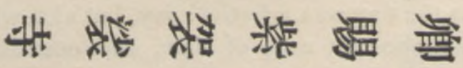

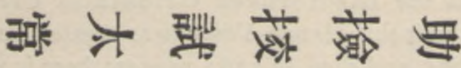


(Below the Inscription, partly in Syriac and partly in Chinese, are the notices) :-

(In Syriac.) In the year one thousand and ninety-two of the Greeks (I092-3II = A. D. 78I) my lord Yezdbûzîd, Presbyter and Chorepiscopos of Kumdân ${ }^{1}$ the royal city, son of the departed Meles, Presbyter of Balh, city of Tehuristân, erected this stone tablet, wherein are written the disposition of our Saviour, and the preaching of our fathers to the kings of the Chinese ${ }^{2}$.

(In Chinese.) The priest Ling-pâo.

(In Syriac.) Adam, Deacon, son of Yezdbûzîd, Chorepiscopos; Mar Sergius, Presbyter and Chorepiscopos.

(In Chinese.) Examiner and Collator at the erection of the stone tablet, the priest Hsing T ung.

(In Syriac.) Sabran Yeshu', Presbyter; Gabriel, Presbyter and Archdeacon, and Head of the Church of Kumdân and of Sarag.

(In Chinese.) Assistant Examiner and Collator, the Presbyter Yê-lî, Chief of the Monastery, Director of the Sacrificial Court, and gifted with the Purple Cassock.

1 This was the name given to Ch'ang-ân by the early Mahommedans.

${ }^{2}$ See note on the Syriac at the commencement of the Inscription.

On the two sides of the monumental stone there are about seventy names in Syriac of individuals, connected with the monastery or monasteries, of various ranks, from bishop down to deacon, the clerical names in Chinese of most of them being also given.

On the latest rubbing also, and obscuring some of the Syriac names, there is this note in large Chinese characters:- After its erection ro79 years, in the ninth year of the reign Hsien-făng (I859), I, Han T'âi-hwâ of Wût-lin, came to see the monument, and, glad to find the characters all perfect, I rebuilt the shed that covers it. Alas, that my old friend, Wû Tsze-pi-the Treasurer-has not been able to accompany me on the visit! I grieved long because of his absence.'

We do not know who this Mr. Han was, nor what authority he had for doing what he did; but the record of his visit shows the interest which intelligent Chinese scholars still take in the monument. 



\section{A LECTURE}

ON THE NESTORIAN MONUMENT OF HSÎ-AN FÛ; AND THE PRESENT PROSPECTS OF CHRISTIAN MISSIONS IN CHINA.

SHEN-HSî is a province of considerable size in the north-west of China, extending to the Great Wall on the north, and on the south to the still larger province of Sze-ch wan, though it has itself an area 16,000 square miles larger than all England. The principal $f \hat{u}$, that is, department or prefecture, in it is that of Hsî-an, which we were accustomed, not many years ago, to call by the names Sî-gan and Sî̀-ngan. Hsî-an cōmprehends at present fifteen districts, the chief of which is Chang-an, with the city of the same name, than which no other city of the empire has played a greater part in Chinese history. Near its site, for we can hardly conceive of it as having then more than begun to be, were the capitals of Wân and Wû, the founders of the Châu dynasty in the 12th century B.C. Near it was the capital of the first imperial dynasty,- that

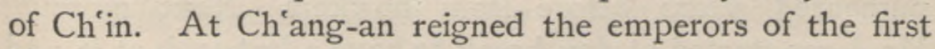
Han dynasty from B. C. 202 to A. D. 24. There reigned the emperors of Sui from 589 to 618 ; and of the two capitals of the great dynasty of $\mathrm{T}^{\prime}$ ang which succeeded to Sui and ruled from 618 to 906, Ch'ang-an was the first and greatest.

The Rev. Dr. Williamson and the Rev. Jonathan Lees, both of whom I know well, visited Ch'ang-an in I866. As they approached the walls, Dr. Williamson says, the sight was imposing. They were lofty and the towers over the gates were magnificent;-in one of them could be counted forty-eight windows. When they had obtained admission, they were conducted to an inn by back streets which appeared endless. Next day they obtained a good view of 
the city from a favourable point on the wall. It struck them as immense and densely filled with houses, having few or no vacant spaces as in other cities ${ }^{1}$.

Many of its ancient monuments attracted their attention, and they particularly mention two of them. One rejoiced in the names of 'the Forest of Tablets' and 'the Palace of Tablets,' containing monuments from B. C. Ioo downwards, and especially the grand set of stone Tablets, on which the text of what we call the Confucian Classics was all engraved in the reign of the emperor Wăn of the T'ang dynasty, the work being begun in 833 and completed in 837. The visitors found the tablets apparently unblemished, and men at work taking copies from them. How would Biblical scholars all over the world rejoice if they were introduced to an enclosure exhibiting engravings in stone of all the books of our Old and New Testaments, executed 1050 years ago, and still complete and exact!

From this Palace of Tablets my friends hurried away to find another monument rather older than the above; the Nestorian tablet which is the subject of my Lecture to-day. They found it outside the walls in a suburb, within a brick enclosure, amidst heaps of stones and rubbish, but itself sound and entire; recognising it at once from rubbings, or facsimiles, of it in their possession, which they had purchased years before from hawkers. Next morning Mr. Lees started at day-break to have a last look at it, and to take drawings of some portions of it. It is to him we are indebted for the singular figures that form the ornamentation round the title, his representation of which further study of them may somewhat modify, and also for the cross immediately above the title. The process which secures exactly the form of the incised characters fails to bring away copies of any raised work.

So much by way of introduction. The monument purports to have been erected, as we shall see beyond

\footnotetext{
${ }^{1}$ See 'Journeys in North China, Manchuria, and Eastern Mongolia; with some account of Corea.' By Rev. Dr. Williamson ; London, I870.
} 
a doubt that it was, in $78 \mathrm{I}$; but our knowledge of it does not go nearly so far back, and dates only from 1625 . In that year some workmen, digging the ground in a suburb of Chang-an, for a grave or for some other purpose (for there are different accounts of the matter), came on a stone monument of large size, and with a remarkable inscription on it, written mostly in Chinese characters, but having others entirely different, and evidently belonging to some other language, interspersed with them. And how strange the things which it told! It said it was 844 years old, and that so long back there had been many strangers there from other countries, preaching and teaching things not to be found in Confucius, or Lâo-tsze, or in all the books of Buddhism; yea, preaching and teaching those things with the sanction and encouragement of the most famous monarchs of the great $T^{\prime}$ ang dynasty which was but a memory of the past. How could it be? The stone was taken out entire, and the discovery excited a great deal of curiosity. The nôtice of the governor of the city being called to it, he took it into his charge, placed it for a time under a cover, and finally deposited it in a Tâoist temple or monastery in the neighbourhood. The only foreigners then in China were Roman Catholic missionaries, and there were none of them at that time in Ch'ang-an. A small mandarin, however, in the city, a convert, thinking it would interest the fathers, had a copy taken of it (I suppose of the Chinese portion only), and sent it to a company of them who were in hiding from persecution in Hang-châu Fû of Cheh-chiang. Among them was Alvarez Semedo, Procurator of the Provinces of China and Japan. In his 'History of the Great and Renowned Monarchy of China ${ }^{1}$,' he tells us that the news from their friend in Chang-an was received by them with 'a spiritual jubilee ;' and according to Athanasius Kircher in his 'Prodromus Coptus sive Aegyptiacus ${ }^{2}$,'they forthwith published and circulated copies

1 'Translated from the Portuguese, by a person of quality ;' London, 1620.

2 Romae, $16{ }_{3} 6$. 
throughout the empire, as supplying a most important proof of the early introduction of Christianity into it, and being admirably calculated to aid them in prosecuting their own labours.

Semedo tells us that he went himself to Ch'ang-an in I628, and took many opportunities to examine and study the monument, ever more and more delighted with it. The inscription, being in Chinese, he could understand; but the other writing that was on it he could make nothing of. He saw that it was neither Hebrew nor Greek; but more about it than this he could not tell. It was not till he was on a visit to Cochin, that he learned at Cranganor, from Father Antony Fernandez, that the strange writing was Syriac, though even then he does not seem to have understood the true character of the monument. However, the missionaries translated the Chinese into Portuguese, had' a copy of the whole monument taken, and sent it home to Lisbon. The bruit of it soon went to Rome, and the copy was carried thither. The Portuguese version of the Chinese was again turned into Italian, and the whole appeared in the head quarters of the Jesuit Missions in 1631 , only six years after it had been excavated from its grave in Chang-an. Athanasius Kircher, a man of various research, and then occupying the chair of mathematics in the Roman College, gave, as I have already stated, an account of its discovery in 1636 . Later on he returned to the subject in his ' China Illustrata,' published at Amsterdam in 1678 , and gave a transcript of the Chinese, made at Rome in 1644 by a Christian Chinese, who is styled Matthew, a native of Hsî-an Fû. The transcript abounded in errors; and Kircher accompanied it with two versions in Latin, one professing to be verbal, executed by P. Michael Boym, a Pole, and the other more diffuse and paraphrastical, in the preparation of which he must have been assisted, I suppose, by Boym and other returned missionaries. At the same time he reproduced and explained all the Syriac portions. The whole inscription 
was thenceforth before all Europe as well as China, challenging critical judgment.

Its reception was different in the East and the West. Scholars in China are, many of them, not less devoted to antiquarian research than their brethren in Europe. I have before me a 'Great Collection of Inscriptions on metal and stone,' in I 60 chapters ; published in 1805 , when he was at the age of eighty-two, by a Wang Ch'ang, who had filled some of the highest offices of the state. It deals with nearly a thousand inscriptions from about 2000 years B. C. down to A.D. 1264 . A large portion of the 102nd chapter is occupied with the Nestorian monument. The whole Chinese text is given, not quite correctly indeed, but much more so than in Kircher. Various points are clearly explained, and there is a review of the opinions of many previous antiquarians on it since its recovery. Not a few of its statements are to himself, as they had been to them, unintelligible and incredible; but no doubt is expressed as to its genuineness. So far as I am aware, a Chinese scholar has yet to appear who will charge it with being a forgery.

It was different in Europe. La Croze, Voltaire, Spizelius, Bishop Horne in this country, and others, contended that it was a fabrication of the Jesuits. Their contention has hardly ceased. In our own day, the late Professor Neumann of Münich, Stanislas Julien of Paris, and the still living Ernest Renan have all more or less impugned its genuineness. In I 853 , E. E. Salisbury, Professor of Arabic and Sanskrit in Yale College, Connecticut, published an article to justify a belief which he had expressed that the monument was now generally regarded by learned men as a forgery. Its defenders, on the other hand, have not been idle. Two among them deserve especial mention. One is the late Alexander Wylie, who published at Shanghai in 1854 a translation of it, much superior to any that had previously appeared, followed by a series of discussions, based on the consensus of Chinese antiquarians and on a 
great variety of historical, biographical, and topographical notices in its details, which seemed to put its genuineness beyond doubt ${ }^{1}$. The other is the late G. Pauthier, of Paris, who, acknowledging the value of Mr. Wylie's labours and taking advantage of them, went himself beyond them, and elucidated every subject connected with the monument, with a fulness of evidence which leaves nothing to be desired ${ }^{2}$. I will for the present therefore assume the genuineness of the monument, and proceed to give a brief account of the contents of the Inscription, with a reference, as I pass on, to a note by Gibbon under the section devoted to the Nestorians in the forty-seventh chapter of his celebrated history. 'The Christianity of China between the seventh and the thirteenth century,' he says, ' is invincibly proved by the consent of Chinese, Arabian, Syriac, and Latin evidence. The inscription of Si-gan-fû, which describes the fortunes of the Nestorian Church from the first mission, A. D. $6{ }_{3} 6$, to the current year $78 \mathrm{I}$, is accused of forgery by La Croze, Voltaire, etc., who become the dupes of their own cunning whilst they are afraid of a Jesuitical fraud.' The sweeping assertion in the former of these sentences requires much modification, as will be seen by and by; but the judgment in the second is a fine instance of the all but unrivalled critical faculty of the writer. I am prepared to affirm it, not only against the scholars whom he mentions, but against all others who have followed in their course. They have been the dupes, I will not say of their own cunning, but of their prejudice and ingenuity.

To proceed then to the contents of the Inscription :- It

1 These were all republished in the Journal of the American Oriental Society, vol, v.

${ }^{2}$ De l'Authenticité de l'Inscription Nestorienne de Si-ngan Fou. Paris, I857; and L'Inscription Syro-Chinoise de Si-ngan Fou, Monument Nestorien élevé en Chine l'an 781 de notre ère, et découvert en 1625 ; Texte Chinois accompagné de la pronunciation figurée, d'une version latine verbale, d'une traduction française de l'Inscription et des commentaires Chinois auxquels elle a donné lieu, aussi que de notes philologiques et historiques, 1858 . 
professes to relate (though this is not its only object), the diffusion of 'the Illustrious Religion of Tâ Ts in,' which is the name adopted for Christianity, in China from 635 to $78 \mathrm{r}$. Of this country of Tâ $T s^{\prime}$ in the writer gives an account in the ninth paragraph, which is to myself, and will be to most readers, the one unsatisfactory portion of the whole, giving us no definite information. He says in the fourth paragraph that 'A virgin gave birth to the Messiah in Tâ Ts 'in,' and we have no doubt that by the name there Judea is intended. There it was that the Illustrious Religion originated. But the little territory of Judea by no means satisfies the application of the name $T \hat{a} \mathrm{~T} s$ in throughout the Chinese histories, and not even the requirements of the ninth paragraph itself. The same country is mentioned in Chinese histories and books under three

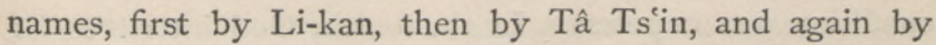
Fû-lin. To determine what country was meant by these names has become, during the last forty years, quite a department of literature among Chinese scholars ${ }^{1}$. The general conclusion seems to be that the names all denote the Roman Empire of the East. It is sufficient for me in this Lecture to rest in the conclusion that by 'the Illustrious Religion of Tâ Ts'in' in the Inscription, Christianity is denoted.

The Contents are threefold:-Doctrinal, Historical, Eulogistic. The first part gives a brief outline of the teachings of the Religion, and of the Ways and Practices of its Ministers; the second part tells us of its first entrance into China, and of the patronage extended to it for the most part for nearly 150 years by various emperors; in the third part to which, though it be the shortest, the two others are introductory, the Christians express in verse

1 See the very able and exhaustive discussion of the subject by Dr. Hirth :'China and the Roman Orient. Researches into their ancient and mediaeval Relations as represented in old Chinese Records.' Leipsig and Munich; Shanghai and Hong Kong, 1885. 
their praise of God and their Religion, and also of the Emperors whose protection and favours they had enjoyed.

In the Doctrinal portion, though there is no enunciation of the articles of a creed, there is much that is well deserving of attention. The first paragraph declares at once the existence of a personal God, Himself uncaused, but the Cause of all else that exists; the Creator; unchangeable; mysteriously existing; the First and the Last; Three-in-One. The second refers to some of the processes of creation, and finally to the formation of man with the harmony of all good qualities, and to have dominion over the earth and all creatures. The third describes what we call the Fall of the first man, and the subsequent degeneracy of his descendants, till they were utterly lost in the mazes of error, and their condition was hopeless. In the fourth, God interferes for the help of men, and the Messiah is born of a virgin in Tâ Ts'in. Angels proclaim the good tidings. His birth is made known to-Persians by a star, and they come with tributary gifts to hail His appearance. The work of His life is then set forth under various aspects, till $\mathrm{He}$ has defeated all the wiles of the devil, and ascends at noon-day to His true place. His crucifixion, death, burial, and resurrection are not mentioned; but $\mathrm{He}$ leaves behind $\mathrm{Him}$ twenty-seven standard-books, - the books, no doubt, of our New Testament. Reference is vaguely made to the washing of water and the Spirit, and to the making of men perfect in the whiteness of humility.

In the fifth paragraph the Inscription passes from the Messiah to His ministers. Though His crucifixion, we have seen, is not mentioned, they carry with them the sign of the cross. They live in communities, and several of their ceremonies and practices are indicated. They let their beards grow, to show they have their work to do without them, and shave their crowns to show that they have no affections centering in themselves. They have no slaves, and do not seek to amass wealth. They worship 
seven times a day, and once every seven days (that must be, on Sunday) they have a great religious service. The effect of their teaching is to diffuse harmony, goodness, and prosperity throughout the world.

With this fifth paragraph the doctrinal part of the Inscription may be said to end. By another, which is short, relating to the name of the Religion as 'the Illustrious,' and to the necessity of co-operation with its ministers on the part of the Governing Powers, it passes on to the historical part.

Du Halde, in his 'Description de la Chine et de la Tartarie Chinoise,' where he is speaking of our monument, says in a note that it is difficult to judge from it whether those of whom it speaks were Catholics or Nestorians ${ }^{1}$. But certainly we find nothing in the Inscription to indicate that they were Roman Catholics, and no mention of the Papal See; while on the other hand, to say nothing of the Syriac names and writing which abound in it, there is the entry in the last column that the stone was 'erected in the days of Hanan-Yeshu', the Catholicos and Patriarch.' Beyond a doubt, the Christians of whom the Inscription speaks belonged to the Nestorian Church.

And yet I should have been glad to learn more from it than I can do of what is regarded as Nestor's peculiar tenet, which brought him into such serious, and to himself disastrous collision with the orthodoxy of the fifth century, as represented by Cyril the Metropolitan of Alexandria. We all know that Nestor or Nestorius, originally a presbyter of Antioch, was raised to the See of Constantinople in 420. Very soon he made himself prominent by inveighing against a common practice among the clergy of styling the Virgin Mary @єото́коs, the 'Mother of God.' 'Has God a Mother?' says he in one of his sermons which has come down to us in a Latin version; 'then is heathenism excusable for assigning mothers to its gods. A creature 
did not give birth to Him who cannot be created; the Holy Spirit did not create God the Word; but from the Virgin He fabricated a Temple for God the Word in which He might dwell ${ }^{1}$ ' Round his denunciation of this expression, surged a great war against Nestor. Other heresies were charged against him; the result was his deposition, banishment, and early death in 448 . What his doctrine really was as to the union of the two natures in our Lord, I have never been able to fashion clearly in my own mind. Canon Farrar in the article Jesus in the new edition of the Encyclopaedia Britannica says that 'Nestor spoke of the two natures in Christ as a connection

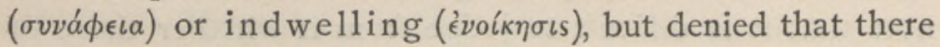
was any communication of attributes; - it was a mechanical rather than a supernatural union of the two parties.' Whether this be a correct representation of the Nestorian doctrine or not, all that I am concerned to point out is that the perplexing point is avoided in our Inscription. The place where it might have been expected is at the beginning of the third paragraph, and there it is only said, 'Hereupon our Triune (Eloah) divided His body (that is, His Godhead), and the illustrious and honourable Messiah, veiling His true Majesty, appeared in the world as a man. A virgin brought forth the holy one in Tâ Ts in.' Other translations of the Chinese characters have been attempted but I cannot construe and render them in any terms but these. The great crux of the Nestorian doctrine was avoided, and very wisely avoided by those who composed the Inscription.

I return from this digression to give an outline of the historical portion. It is in eleven paragraphs, and tells us how Olopun arrived in China in 635 , and was favourably received by the emperor T $T^{\prime}$ â $T$ sung; of their first interviews, and that an imperial edict was issued authorizing

1 Gieseler's Compendium of Ecclesiastical History (Davidson's translation), vol. i. p. 394 . 
the propagation of the new doctrines throughout the empire; and how a monastery was built in the capital and a picture of the emperor painted in it. Then, in seven more paragraphs, the fortunes of the Illustrious Religion are traced down to the year 78I. In all the successive reigns one sovereign seems to vie with another in acts of favour, with a single exception. The period of T'âi Tsung's son and successor Kâo Tsung was one of great progress. The religion is represented as spreading far and wide; and monasteries were built in a hundred cities. The next twenty or twenty-five years were a time of disaster and difficulty. From the Inscription we should conclude that there was only one emperor between Kâo Tsung and Hsüan Tsung, but in reality there were two emperors and one supreme usurping empress. Kâo Tsung left the throne to his son, known as Chung Tsung, but he was soon displaced, and a brother, called Jui Tsung, appointed in his room by their step-mother called the Empress Wû. This lady had at one time been a concubine of T'âi Tsung, and on his death withdrew to a Buddhist nunnery, where she assumed the monastic garb and vows. After his accession Kâo Tsung took her from the nunnery into his harem, where by and by she supplanted his acknowledged empress and took her place. A woman of extraordinary ability and daring, she set aside first Chung Tsung and then Jui Tsung, and for twenty years kept the reins of government in her own hands, making many changes and being guilty of many cruelties. She was a bigoted Buddhist, and we may well suppose that she hated the Nestorian strangers, and that her co-religionists were jealous of the favour shown to the Illustrious Religion. Now was their opportunity. Christianity was slandered and persecuted, and it was only by the prudence of some of its principal followers that it was piloted safely through the storm and, as the Inscription says, its damaged net preserved from utter ruin.

Happily the time of danger did not last long, and on the 
accession of Hsuian Tsung in $7 \mathrm{r} 3$ the sun of prosperity redawned. The broken edifices were restored. Special tokens of imperial favour were sent to the original monastery. Men of more than ordinary ability came from the west to strengthen the mission. We might even hope that the emperor Tai Tsung became a real convert, if we did not know that he gave the Buddhists similar reasons to claim him as a true disciple of Gotama. There came from Râja-griha in India a man who appears to have joined the Nestorian community; and rising to eminent employments in the state threw all his wealth and influence into the promotion of the Christian cause, manifesting especially an extraordinary charity.

We are brought to the emperor Teh Tsung, who began his reign in 780 . All is serene in the state; all is bright with promise for the Illustrious Religion. Full of gratitude in their review of the past, and rejoicing in hope for the future, the Nestorian leaders prepare their monument; and in $78 \mathrm{I}$ they raise it up, and proclaim by it their praise of God, and of the various emperors who had been in so remarkable a manner the patrons and promoters of their enterprise. Of their eulogistic verses I do not need to say anything. Half a dozen short hymns used in the services of the monasteries would have been more valuable. They give us no information beyond what we have in the two preceding parts of the Inscription; and the sixty-six lines of which they consist do not seem to me to possess, as Chinese verses, any remarkable merit.

Let me return, and consider more particularly the historical notices in the second part. It is not difficult to say, approximately at least, from what neighbourhood in Tâ Ts in, the Far West from China, Olopun must have gone forth. At the time of the erection of the monument, the Nestorian patriarch it is said on it was Hanan-Yeshue. The year, it is said, was A. D. 781 , but we know from Assemani ${ }^{1}$ that this 
patriarch had died in 777 or 778 , though this error of date, so far as he is concerned, only confirms the genuineness of the monument. At his appointment, the seat of the Patriarchate was at Seleucia, but the Bishops and others concerned not being able to agree between him and another candidate, the Caliph of the day, who was Al Mahdî, the third of the line of the Abassides, transferred the election to Bagdad his capital, and caused it to be made under his own eye. After the death of Nestor his views had continued to be taught at Edessa, and when the school there was suppressed by the emperor Zeno in 489 , the Nestorian teachers moved eastwards under Persian protection, to Nisibis, where Yesu-Yabus, a native of Gadala in Arabia, and who must have been patriarch when Olopun commenced his long and perilous journey to the east, received his education.

The propagation of Christianity in its Nestorian form was carried on with wonderful energy and success in those early centuries. Persia, Bactria, India, and other regions were all more or less evangelized, and I like to think of Olopun, after long musing and contemplating a still more distant enterprise, starting from somewhere in Mesopotamia, perhaps about 630 , and directing his way to China. What route he pursued we can only tell in a very general way. My idea is that he journeyed at the head of a considerable band of other monks, all animated with the same zeal as himself for the propagation of their faith. They would go from west to east with many a détour, finding their way from monastery to monastery in the same way as we know that the Buddhist pilgrims Fâ-hien, Hsuian Chwang and others pursued their course in the opposite direction from China to India. At length in 635 they are at the gates of Chang-an, the capital of China ; and as.I read between the lines of the Inscription, I cannot help supposing that there had been some previous communication between Olopun and the Emperor. My mind has always gone from this part of the account to the entrance 
of Buddhism into China in our first century. Then the Han emperor Ming had somehow become curious about Buddha and his books. In consequence of a dream, which is probably merely a semi-supernatural version of the story, he sent messengers to India in A.D. 6I, to bring back an image of Buddha and some of his books. They returned in 67 or 68 , bringing with them an image and a book, and also two Indian monks, whom the emperor welcomed to Lo-yang, his capital, assigning to them for their residence a monastery. So was the first foreign religion that entered China received, and in a remarkably similar way was Christianity, as we see from this monument, received nearly 600 years afterwards. There was not in those times the shrinking from foreigners and foreign religions that there came to be subsequently. I may have a few words to say on the reason of the difference before I have done.

When it was proclaimed by $T^{\prime}$ âi Tsung that the teaching of Olopun and his associates should be allowed to have free course in his dominions, there were now four religions in China, each claiming to be superior to the others. Not to go farther back than the sixth century B. C., there had been the two indigenous religions;--what we call Confucianism and Tâoism, which had never agreed well together. Sze-mâ Chien, writing in the second century B.C., tells us that they discountenanced and discouraged each other, not being able to walk together through want of agreement in their fundamental principles ${ }^{1}$. Buddhism came into the field in our first century, and there was antagonism between it and them both. And now there was in the Nestorian form of Christianity a fourth claimant on the faith and homage of the people. How Buddhism behaved to it, we have already seen. From the language of our Inscription I draw the conclusion that the Nestorians took more kindly and appreciatingly to Tâoism than to Buddhism. Confucianism used to describe itself by the name of 'Instruction ${ }^{2}$;' Tâoism

1 See his life of Lâo-tsze in the third of his 'Biographies.'

${ }^{2}$ See the commencing sentence of the Chung Yung. 
preferred the term 'The Way;' the distinctive name of Buddhism was 'The Law.' All the three terms are used by the Nestorian writers for their system. Now it is the Instruction or Doctrine, and this is the special name which they devised for it: 'The Illustrious Chiâo,' meaning System of Instruction, Teaching, or Doctrine; anon they speak of it as 'The Way;' and again as 'The Law.'

But their composition indicates a greater familiarity with the standard works of Confucianism and Tâoism than with those of Buddhism. The Inscription, however, says nothing against any of the three systems which they found in Ch'ang-an, and there is nothing in it to show that they drew up digests of their doctrines and circulated them among the people. When it is said that Olopun, immediately after his arrival, translated his scriptures in the library of the palace, and discoursed about them with the emperor, I do not think that the real fact would amount to much. He would translate, or superintend the translating of, short and important passages of the Bible, and satisfy Teâi Tsung as to the goodness of their teachings ; and this was sufficient to secure the toleration and favour which Christianity received. Notwithstanding the opposition and persecution under the empress Wû, Nestorianism arrived ' in heart and hope,' having been, to outward seeming, 'a grand success,' at the year $78 \mathrm{r}$, when the monument was erected. Very slight indications of its presence in China are found subsequently in Chinese history, and the curtain drops on the monument till it is dug up from under the earth, after 844 years, in $\mathbf{1 6 2 5}$. This long silence about it has often been used as an argument against its genuineness. It was the good fortune, or merit rather, of M. Pauthier to draw from a source long existing a satisfactory explanation of the silence; and what is of more importance, to account for the stoppage of Christianity in the progress which had so far been made.

We must pass on from $78 \mathrm{I}$ to 845 , the sixth year of Wu Tsung, a space of sixty-four years. During this interval 
there had been a vigorous movement in favour of Buddhism, which was met by strong protest from some of the literati, the uncompromising adherents of Confucianism. In the year 819 , the nineteenth year of Hsien Tsung, orders were issued for the conveyance of a bone of Buddha, a famous relic, to the capital, and to deposit it there within the precincts of the palace, great honours being shown it along the line of route. This roused the indignation of a high officer, Han $\mathrm{Y} \ddot{u}$, one of the most renowned names in all Chinese literature. He addressed a memorial to the emperor against the proceeding, and advised that the bone should be delivered to the proper officers to be cast into the water or into fire, and for ever made an end of. 'If Buddha,' he wrote in conclusion, 'show any efficaciousness, if he can produce calamity or trouble in consequence, let it light on my person. Before High Heaven, I will not murmur nor repent.' This remonstrance led to the degradation and disgrace of the memorialist himself, but I do not suppose that it fell unheeded on the other ministers or on the public. But it was not from the literati that the blow which was soon directed against Buddhism was to come. The Tâoists were on the watch for their opportunity. Two sons of Mû Tsung occupied the throne in succession for brief reigns; and in $84 \mathrm{I}$ it fell to Wû Tsung, who had grown up under Tâoist training, and was entirely subject to the influence of a Châo Kwei-chăn, a slave to all its superstitions, and full of hatred to Buddhism. This man deluded the emperor with promises of the elixir vitae, and visions of immortals; and a grand proscription of Buddhism was determined on. Prior to the proclamation of it an account was taken of the monasteries of the empire, which were found to amount to 44,600 , occupied by more than 265,000 monks and nuns ${ }^{1}$. Then the bolt was discharged:-'Let the Buddhist monasteries be destroyed

${ }^{1}$ See Nien Chang's History of Buddhism (佛组璴他通諓), ch, xyi. 
throughout the empire, and let the monks and nuns all return to the ways of common life.' A few buildings were exempted from the edict, but in general it was ruthlessly carried out. Tens of thousands of acres of land were confiscated; the images, bells, and other metallic instruments of music were melted and coined into copper money; and 150,000 slaves, male and female, were set free ${ }^{1}$. This was a terrible blow to Buddhism, and is known as 'the Third Proscription' of that System in Chinese history. But it was too widely spread and firmly rooted to be destroyed in the country by such a spasmodic effort of a sovereign like Wû Tsung. In the very next year, as the historian of Buddhism tells us, in despite of - rather in consequence ofhis Tâoist pills and charms, he fell ill, sank into a state of moping melancholy, and died, at the age of thirty-three. $\mathrm{He}$ was succeeded by an uncle, who pursued a different policy, and endeavoured to bind up the wounds of the Buddhist state.

But did this persecution affect the Nestorian missionaries and their movement? It did. The text of Wû Tsung's edict still remains, and is included in a Collection of imperial edicts and rescripts published in 1685 by orders of the great $\mathrm{K}$ ang-hsî emperor of the present dynasty, with comments from his own pencil. There is a translation of it in Du Halde's History ${ }^{2}$, supplied, I believe, by P. Hervieu; and in the conclusion it is said, 'As to the religions of foreign nations, let the men who teach them, as well those of Tâ Ts in as of Mû-hû-pî, amounting to more than 3,000 persons, be required to resume the ways of ordinary life, and their unsubstantial talkings no more be heard.' It is the merit of Pauthier that he called attention to this edict in 1865 , and it was his good fortune that he could refer to the original text, there being two copies of the $\mathrm{K}$ 'ang-hsî Collection in the great library of Paris. It could

${ }^{2}$ See a long note on the event in the $\mathrm{T}^{\prime}$ ung Chien Kang M $\mathrm{u}$ under the year 845 .

2 Vol. ii. p. 497 . 
only be from ignorance of the existence of such a document that some have denied that there was ever any mission of Nestorian Christianity in China; but I can hardly blame them, for who is sufficient, even in the course of a long life, with all the difficulties of the study, to make himself familiar with the vast and various stores of Chinese literature?

What was more likely than that our monument should be thrown down when Wû Tsung's edict was issued? I venture to suppose that it was then buried by some of the Christians themselves to save it from being broken in pieces, and that thus it was happily preserved till it was recovered in $\mathrm{I}_{225}$. Who the teachers of $\mathrm{M} \hat{\mathrm{u}}-\mathrm{h} \hat{\mathrm{u}}-\mathrm{p} \hat{\mathrm{i}}$, that were silenced at the same time as the Nestorians, were, cannot be ascertained. We know that there were followers of Manes then in China, and other teachers from Persia. The M û - hû-pî were perhaps Mohbeds or Guebers, the worshippers of fire, whose representatives remain in the Parsi remnant of the old Persians.

Nestorianism never recovered from the disaster of 845 . Wû Tsung's successor, I have said, reversed his antiBuddhist policy; but there arose no emperor who remembered Olopun. The 3,000 suppressed monks were an insignificant number compared with the 265,000 monks and nuns of Buddhism. Their mission had received its deathblow. Some would wander westwards to the nearest sees of their religion; and those of them who were of Chinese extraction would disappear amidst the masses of the people. Very little is heard of them in subsequent Chinese history. It may almost be said of the Nestorianism which appeared for two centuries with its head-quarters in Hsî-an Fû, that it sustained an entire collapse in China,

'And like an unsubstantial pageant, faded, Left not a rack behind.'

The T'ang dynasty passed away in 906, and after little more than fifty years, occupied by five feeble dynasties, was 
succeeded in 960 by that of Sung. Then came what has been called the Augustan age of Chinese literature, when the battle of Confucianism was fought out against Tâoism and Buddhism on grounds of reason and philosophy. During the three hundred years of its duration at two different capitals, however, a modus vivendi was introduced among the three, till the empire of Jinghis Khan arose, swept over China as over most of the rest of Asia, and threatened the nations of the West. In 1260 one of Jinghis' sons, known as Shih Tsû or Kublai, became emperor of China, and the Yüan or Mongol dynasty was established. During his reign the two elder Polos found their way to his capital at Yen-king, not far from the present Peking, and were sent back by him with a letter to the pope. On their return with Marco the son of one of them, he became a favourite with Kublai, and remained in China for seventeen years, being employed often in offices of trust, and at one time governor for three years of the great city of Yang-châu, which I have seen. On his return to Europe he wrote his famous book giving an account of his travels. Nestorians are mentioned in it, but the notices of them are few and far between; and it does not follow that those whom he met with were descended from the converts of the early missionaries at Ch'ang-an and other places. He tells us, for instance ${ }^{1}$, that in what is now Chin-chiang Fû of Chiang-sû province there were two Nestorian churches, but he adds that they had both been built by Mar Sarghis (or Sergius), who had been sent there by Kublai as governor in 1278 , and that there had been none there before. This Mar Sergius would be himself a Nestorian from some of the patriarchates in the West, and animated by the spirit which had led the missionaries six and seven hundred years before to Ch'ang-an. Similar may have been the case in all the other instances where Marco Polo speaks of Nestorians as being in China in his time. He visited Hsî-

${ }^{1}$ Chapter 148 of Pauthier's edition; Yule, vol. ii. p. I6r. 
an Fû, which he calls, according to Pauthier's transliteration, Quingian $\mathrm{Fu}^{1}{ }^{1}$, formerly the capital, he says, of great and valiant kings, and, when he was there, still very grand and beautiful. 'But the people were all idolaters.' He does not say a word about any memory of the Great monument, or of the Christian work which had been for about two centuries carried on in the place. I must repeat my impression that the Nestorian mission at Ch'ang-an, and branching out far and wide through the empire of $\mathrm{T}^{\prime}$ ang, had been extinguished by the edict of Wu Tsung.

It had proved a failure, and I should like, in bringing my Lecture to a conclusion, to offer some remarks on the causes of its failure and the likelihood of a better issue for other Christian missions which have since succeeded to it, and are at present zealously prosecuted.

For one thing, the greatest successes of the Nestorians were won among people less advanced in civilization than the

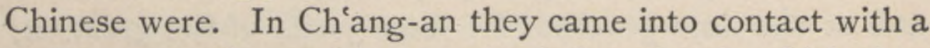
society more thoroughly organized than that in which they had themselves grown up, and possessed of a literature venerable for its antiquity, subtlety, and variety. The scholars of Confucianism had received a higher intellectual training than those who came to teach them; the leaders of Tâoism, versed in the Confucian classics, were strong also in the subtleties and ingenious reasonings of their own peculiar system; the Buddhists looked at the course of events and the facts of human experience from a standpoint new and strange, and called men to a style of life requiring great self-discipline and self-denial, and not undeserving to be called the noble path. Only among the Confucianists was there a recognition of God as the Supreme Ruler, the Author of man's moral nature, and requiring compliance with its highest indications as obedience to His will; and even among them that recognition was not so vivid and powerful as it had been in the earlier ages of the nation's

1 In Yule, Kenjên Fu. 
history. The Nestorians were at a disadvantage in attempting to take possession of such a field with their own theological subtleties. They would fight for the most part as men who were beating the air; and I am not surprised that, after labouring for a couple of centuries with laudable and self-denying zeal, they should have passed away and left no memorial that ever they had been there but this monument of Hsî-an Fû.

For a second thing, and so far as we can judge from the monument, the Nestorian work in China was directed more to propitiate and conciliate the emperors as the Powers that were, than to enlighten and convert the people. There is no entry in it of the increase of believers, or of additions made to their Societies; while the favours shown to them by the government are celebrated in flattering and even fulsome terms. I do not blame Olopun and his friends for paying court to the rulers of the country and obtaining their sanction to their residence in it. In no other way could they have found admission to it and obtained a foothold. And in the same way Christianity was introduced into our own and other countries. As Olopun solicited an interview with $T^{\prime}$ âi $T$ sung when he drew near to the walls of Ch'ang-an, so did Augustine, when he landed in the isle of Thanet, in the sixth century, ask to be received by king Ethelbert. Nor do I say that the missionaries did not take advantage of the imperial favour to work out from their monasteries among the people. They must have done so. How else could they be supported? The government might give them the ground for their monasteries and even erect some of the buildings for them; but it would not regularly pay them salaries. I suppose too that supplies rarely and scantily, if at all, came from the West. Their converts would contribute to their support according to their ability. The monument commemorates in one paragraph the liberality in giving to the monasteries of $\hat{\mathrm{I}}$-sze, who would appear to have come as a Buddhist from Magadha in India, and to have embraced in Chang-an the 
more excellent way of Christianity. Thereafter, having raised himself to eminent employments in the state by his talents, he laid nothing up for himself, but imparted all that he received to the strengthening of the mission, and to helping the necessitous. 'He fed the hungry, clothed the naked, healed the sick, and buried the dead.' But this is a solitary instance in the Inscription of the operation of the Christian truth believed and obeyed. We cannot but come to the conclusion that the Nestorian teachers thought it their better way to work downwards from the apex of society rather than to work upwards from its foundations. What else could they do in their circumstances? many will be ready to ask. But the end showed that they were mistaken in thinking that to receive the smiles of the court and have the pictures of the emperors displayed in their halls were real triumphs of Christianity.

For a third thing, we cannot but deplore the absence from the Inscription of all mention of some of the most important and even fundamental truths of the Christian system. The personality of God and His Triune Being stand out prominently in it, as also the Incarnation of the Messiah and His appearing as a man. His fulfilment of the old Law, and His own legislation for the good of mankind, and His setting in motion of the vessel of mercy for the deliverance of the quick and the dead are set forth; but not a word is said about His miracles, or anything specially bearing on His crucifixion, His death, His burial, and $\mathrm{His}$ resurrection. There is little in it particularly ritualistic, but there is nothing at all evangelical. It is too passionless altogether for the mission which it commemorates to have been the centre of a vigorous propagandism. Talking once about Nestorianism in China with one of the most zealous living missionaries, I asked him to what he attributed its failure. His reply was, 'How could it succeed? There was no Gospel in it. How do you account for the failure?' I replied that I attributed its failure to its leaders addressing themselves to the emperors and men in power, 
and placing their reliance so much on them. The two things, no doubt, operated together, and hence it was that the movement which for a time promised so much passed away as rapidly as it arose.

After Nestorianism had disappeared, the Church of Rome, in the thirteenth century, began to turn its attention to the evangelization of China, and Pope Nicholas IV sent John de Monte-Corvino to the East. He was favourably received by the emperor Kublai, the patron of Marco Polo, and was soon able to send to Europe such accounts of his success that Pope Clement V, in $\mathrm{I}_{307}$, appointed him archbishop of Khanbalik, or Kambalu, that is, the city of the Khan, and sent seven other monks to act under him as suffragan bishops. The scanty notices that we have of this movement leave on the mind a favourable impression both of the men and their measures. They belonged to the orders of St. Francis and St. Dominic, but nothing great and permanent came from their labours.

We must come down to the close of the sixteenth century to find the commencement of the great Roman Catholic missions in China which are still prosecuting their work. Father Michael Ruggiero, or Roger, reached the Empire from Goa in 1579 , and in 1581 he was joined by Matteo Ricci, a native of Italy, and they must be regarded as the founders of the Jesuit missions in the Chinese Empire. Ricci especially was a man amongst men. Intended originally for the profession of the Law, he had entered the Church and become a Jesuit. He was a man of great scientific acquirements, of invincible perseverance, of various resource, and of winning manners, maintaining with all these gifts a single eye to the conversion of the Chinese, the bringing the people of all ranks to the faith of Christianity. The time was gone by when the emperors would welcome foreigners, and even the propagators of new religions, to their dominions, as had been done under the Han, the T'ang, and the Yuen dynasties. They had begun to be afraid of the nations of the West, which had been 
brought, in the progress of maritime discovery, within easier reach of China. Roger and Ricci found it difficult to obtain any footing. If they had been men of less earnestness they would have abandoned their enterprize and returned to Europe; if they had been men of inferior qualifications they would have been forced to abandon it. But they maintained their hold and improved their position. By his linguistic ability, his science, and his adroit management, Ricci succeeled in establishing himself first at Châoch'ing, the old metropolis of Canton province, and then at Nan-chang, the metropolis of Chiang-hsî; and finally he made his way to the capital, and was favourably received by Shăn Tsung, the Ming emperor of the Wan-lî period, and there he died in 1610 . During all this time he had been writing learned works, mostly on mathematical science, and also catechisms and other books explaining the principles of the Christian religion. His converts were not a few, and amongst those of high rank was a member of the Han-lin College, called Hsü Kwang-hsî, who afterwards assisted him in translating Euclid into Chinese. Hsii was baptized by the name of Paul, and the confession which he witnessed at his baptism has fortunately been preserved ${ }^{1}$. I have heard the confessions of many good men when they were being admitted to the membership of some of our stricter churches in this country; but I never heard one more simple in its statements, or more devout in its spirit than that of this Hsü. He filled some of the highest offices of the state, and was possessed of large property. One of his daughters was also baptized by the name of Candida, and, according to Du Halde, consecrated her wealth to the cause of Christianity, building thirty-nine churches in different provinces, and printing for circulation 130 Christian books. Some of us have read recently of the employment of blind men in nooks of Peking to disseminate a knowledge of the Scriptures by reading aloud portions prepared and

${ }^{1}$ See the Abbé Huc's 'Christianity in China, Tartary, and Thibet,' vol. ii. pp. 172,173 . 
printed for their special use; Candida anticipated this good expedient, for, seeing many blind people telling idle stories in the streets for their living, she got them instructed and sent them forth to relate the events of the Gospel history.

But let me not use up the time with such details. On Ricci's death, his colleague Pantoja and others obtained from the emperor a piece of ground in which to bury him, and Roman Catholicism thus took possession of a portion of the soil of China.

Other Jesuit missionaries, not inferior to Ricci, came into the field, men such as Adam Schaal and Verbiest. Franciscans, Dominicans, and members of other orders also pressed into it. The dynasty of Ming, moreover, was drawing near to its close, and the Manchûs were preparing for the conquest of the Empire. Many difficulties and perils encompassed the missionaries, but Schaal was able to maintain his position at Peking by his astronomical knowledge in correcting the calendar, and by establishing a foundry where he cast cannon to be used against the Manchûs. And this position he continued to hold when the Empire fell to those invaders. He was made head of the Board of Astronomy and Mathematics, and was a favourite with the first Manchû sovereign, though he did not shrink from remonstrating with him against certain severe measures, and urging him rather to justice, forbearance, and mercy. He was able to lay in 1650 the foundation of a grand church in the neighbourhood of the imperial palace.

When the second emperor, known to us as $\mathrm{K}^{\prime}$ ang-hsi by the name of his reign, succeeded to his father at the early age of eight, there was trouble during the minority; but as soon as he took the government into his own hands, he gave his full confidence to the missionaries. He was, probably, the most able and enlightened sovereign who ever sat on the Chinese throne, and his reign lasted sixtyone years. Schaal and Verbiest regulated the calendar and cast cannon for him; Regis and several others conducted 
for him the survey of the Empire, which Rémusat correctly describes as 'the most complete geographical work ever executed out of Europe.'

But during the $\mathrm{K}^{\prime}$ ang-hsî reign, evils that had been growing among the missionaries themselves reached a head. Ricci had been too liberal in his views about the use of religious terms and ritual practices, not only for the Dominicans and Franciscans, but also for some of his Jesuit brethren. Did the Chinese really mean GoD when they spoke of T'ien (Heaven) and Shang Tî (the Supreme Ruler)? and might the converts be permitted still to use those terms? Was it really religious worship which they paid to Confucius, and to their parents and ancestors in their mourning rites, or merely the expression of their grateful homage to the Sage, and of their filial piety? and might the converts still be allowed to pay it ? Ricci had replied to these questions in the affirmative. About the terms I entirely agree with his opinion, nor do I altogether differ from him about the ritual practices. But as time went on, the differences among the missionaries became wider, and their controversies waxed hotter. The objectors urged that the practices were a sanctioning of idolatry. The Emperor and the Pope were both appealed to. The emperor gave his judgment in favour of Ricci's views; but the papal judgment was in the end against them on both subjects. Who is this pope, thought the emperor, who dares to pronounce and legislate contrary to me in regard to the time-honoured speech and ways of my own subjects? A storm began to gather against the missions, but it did not burst during the K'ang-hsî reign. It burst, however, during the Yungchăng reign of his son and successor.

In 1724 an edict was issued prohibiting the propagation of Christianity, 'the Religion of the Lord of heaven,' in the Empire, and all missionaries not required at Peking for scientific purposes were ordered to leave the country. Many of them in consequence withdrew, and disappeared from China, but there were others who would not forsake 
their flocks. They secreted themselves, and ministered to the converts as they found opportunity at the risk of their lives. Many also in the Chinese Christian congregations adhered to their profession, and on occasions of persecution which arose ever and anon, here and there, were faithful to the death. One thing was plain,- that the converts had been sincere, and that no violence was able to eradicate the Christianity that had been planted in China. So things went on for more than a century, unfavourably, no doubt, for the missions, till the end of our first war with the Empire in 1842 . Then a proclamation appeared, altering for the better the position of the missionaries; and at the conclusion of the second war, in which the French were our allies, in 1858 , an article was introduced into the treaties-British, French, and American-stipulating for the toleration of Christianity, and for the protection of missionaries, whether Roman Catholics or Protestants. In the French treaty it was added that all which had heretofore been written, proclaimed, or published by order of the government against the Christian religion, was completely abrogated and no more to be of force in any of the provinces of the Empire. There were other conditions in a supplementary convention insisted on by France, which to my mind were unjust, and must prove to have been unwise; but I need not speak of them, and hurry to a sketch of the history of our Protestant missions, and their present prospects,- the only other subject in which I wish to touch in this Lecture. It cannot be said that I have spoken with Protestant prejudice of the Roman Catholic missions. I do homage to the ability, perseverance, and devotion of many of the missionaries, and to the wisdom of their methods. They deserved success, and they gained it. If they sought the imperial favour too much, and made doubtful concessions to obtain it, as I said of the Nestorians, what else could they have done in their circumstances?

The pioneer of Protestant missions was the Rev. Robert Morrison, who, leaving England early in 1807 , and taking 
passage of necessity in an American vessel from New York, arrived at Macao in September of that year, just two centuries and a quarter after Ruggiero and Ricci arrived at the same place. The Yung-chăng edict was still in force, forbidding the propagation of Christianity, and the aversion of the government to free and friendly intercourse with foreign nations had become more intense. A dread of western nations had commenced, I said, with the first opening of communication by sea between the West and the East; what it had learned of the progress of British conquest in India, and our most unhappy and unrighteous pressing on the people of our Indian opium, in spite of its resistance and protest, had inflamed its dislike to the admission within its borders of 'the outside barbarians,' as it foolishly considered and designated all other peoples. Morrison dared not make himself known openly as a missionary. Even the oldest and best-known foreign merchants were allowed to reside in Canton, unaccompanied by their wives, only one half the year for the transaction of their business; for the rest of it they had to live in the Portuguese settlement of Macao. Among the merchants and gentlemen of the East India Company's Factory, however, Morrison found friends; and he went to Canton under the shelter of an American firm, and prosecuted, amidst extraordinary difficulties, the study of the language. Far inferior to Ricci in scholarly training, he was not inferior to him in indomitable perseverance, and cherished equally the high ulterior aim of the missionary. His instructions were that, having acquired the language, he should address himself to the translation of the Scriptures and the preparation of a Chinese and English dictionary. So rapid was his progress that in 1809 he entered the service of the East India Company as translator to their factory; and in this office he continued till the abolition of the Company; and afterwards, till his death, he held the same appointment in connection with the new arrangements for the conduct of the trade with China. His appointment secured his residence at Macao and Canton, furnished him 
with a sufficient income, and enabled him to prosecute his labours. But it should be said that he never sought to become wealthy. The more he had, the more he gave away, in the promotion of philanthropic and Christian schemes. His missionary spirit never became less earnest. In the last letter which he wrote in 1835 , amid the diffculties and threatenings that accompanied the changes in the superintendence and conduct of the trade, he said, 'I wait patiently the events to be developed in the course of Divine Providence. The Lord reigneth. If the kingdom of God our Saviour prosper in China, all will be well. Other matters are of comparatively small importance.'

In $1_{1}{ }_{13}$ the Rev. William Milne arrived at Macao to join him as a missionary colleague, but was unable to remain in consequence of the bigoted opposition of the Portuguese priests, and soon betook himself to the Indian Archipelago, to do what Christian work he could among the many Chinese emigrants distributed at various places. He settled at Malacca, where in a few years he carried out a favourite scheme of Morrison in the building of the Anglo-Chinese College, in which Chinese and foreigners might have opportunities for the reciprocal cultivation of the languages and literatures of their different countries.

In 1814 Morrison printed the whole of his version of the New Testament. In a portion of it he had been assisted by a manuscript which he had found in the British Museum, and had been able to copy out and carry with him by the help of a Chinese whom he had met with in London. In going on to the Old Testament he was assisted by Milne, and the whole of the Bible was printed in $18 \mathrm{I} 8$. As a version of the original Hebrew and Greek, it was executed very imperfectly and not calculated to last long. Such as it is, however, I have never ceased to marvel how the men were able to produce it, so soon after the commencement of their Chinese studies.

His labour with the dictionary, which expanded in his hands to six quarto volumes, was never intermitted. The 
first and most elaborate volume appeared in 1817 , and the last in 1823 , published at the expense of the East India Company. Parts of it have not been superseded by later dictionaries, though the whole has been largely supplemented. There is no finer monument of human perseverance than the dictionary of Dr. Morrison.

During all these years other missionaries from England had been following to the East; and as they could not enter China itself they occupied different stations in the Archipelago, at Malacca, Penang, Singapore, Batavia, and elsewhere. There they waited, expecting till the door should be opened for them, establishing schools, teaching and preaching, publishing short Christian treatises, and gathering round them a few converts.

The Rev. Samuel Dyer, who had been educated at Cambridge, conceived the idea of superseding the Chinese method of printing from wooden blocks by moveable metallic types, and commenced the making of two fonts of different sizes. Matrices from both the fonts.which he thus commenced, to the number of more than 6,000 characters, are now part of the furniture of the Clarendon Press.

Missionaries from America began meanwhile to resort to Macao and some of the stations in the Archipelago, and also to Burmah and Siam. Then came the treaty of 1842 , dictated to the Chinese at Nan-king, and which closed our first war with the Empire, throwing open five ports for trade, and ceding to Great Britain the island of Hongkong. The time for missions in China itself had at length arrived. The missionaries at the various stations in the Archipelago, myself among them, for I had been at Malacca since the end of 1839 , hastened to a meeting at Hongkong in 1843 , to consult together how we should take advantage of our new opportunities, and also to meet the American missionaries whom we might find there. We came together, certainly not more than a dozen men in all, the most eminent among us being the Rev. Dr. Medhurst, from Batavia, who was at that time the foremost among Chinese 
scholars, and who had left England in 1817 . Dissatisfied with the version of Morrison and Milne, one and another had made versions of the whole or portions of the New Testament; and the most important thing agreed on was a new translation of the whole Scriptures, to be executed by a Committee, the members of which should meet at Shanghâi in three years. At the same time arrangements were made for occupying the five newly-opened ports and Hongkong by different missions. The converts of the past then alive and in China known to the members of the Conference could be reckoned up on the fingers of one hand. Within about ten years of that meeting the translation Committee had completed its work, and the result was a version both of the Old and New Testaments, which for fidelity to the original, and for an elegant and thoroughly idiomatic style, yet not obscure, need not shrink from comparison with any version of our Sacred Books in any language that $\mathrm{I}$ am acquainted with.

Since 1843 missionaries have pressed to China from most of the Protestant Churches of Europe and the United States; and an amount of work has been done and success gained which fills me with astonishment, and affords a bright prospect of greater things in the future.

Without creeping on with details, as I have thus far been obliged to do, I will give a summary of the results, taken from the Report of a Missionary Conference held at Shanghâi in 1877 . At that time there were 473 representatives, male and female, of different Societies distributed over the ever-enlarging field: -222 from thirteen British Societies; 210 from ten Societies of the United States; twenty-six from two German Societies; seven not connected with any Society; and eight who were agents of Bible Societies.

Connected with these there were 312 organized Churches, eighteen of which were wholly self-supporting, and 243 partially so, and having a total membership of $\mathrm{I} 3,035$. In boarding and day schools there were 2,991 boys and 
J,307 girls. Of theological schools there were twenty, with ${ }^{2} 3^{1}$ students; there were seventy-three ordained Chinese pastors and preachers, and $5 \mathrm{II}$ assistant preachers.

A great feature of Protestant missions is their medical agency. In 1877 there were sixteen Hospitals, where in I 876 there had been $3,73^{\circ}$ in-patients and 87,505 outpatients ; there were also twenty-four dispensaries, where in the same year relief and assistance had been given to 4I,28I applicants.

These figures give us some idea of the working and progress of Protestant missions; and all this is the growth of eighty-one years since Morrison went to China; is the growth, I may rather say, of forty-five years since 1843 , when the country began to be opened to missionary labour. The increase has been great during the last ten years. The communicants now can hardly be fewer than 20,000 , representing, with their children and dependents, 100,000 souls, as well deserving to be called Christian as the inhabitants of any parish in this country.

The Empire is in fact being covered with a network of small churches, gathered from among the middle classes and the poor. Of the real Christianity of the majority of their members I have no doubt. I have known some who took joyfully the spoiling of their goods, and some who were prepared to die and did die, rather than deny their faith. The outside world takes little heed of what is going on ; but Christianity is growing in China, without observation, through Protestant missions. And their effect has been great on the higher classes of Chinese society and the members of the government, many of whose prejudices are passing away. If none of them have declared themselves fully and like Hsü Kwang-hsî on the side of Christianity, some of them are efficient helpers in the benevolent and medical departments of the missions. The government itself has its school or college in Peking for teaching other languages; a considerable staff of foreign and native scholars engaged in the translation of scientific 
Works; its arsenals under foreign superintendence at several places; its embassies in Europe and the United States.

There are many great scholars and skilful organizers in the Protestant camps; some contemplating institutions of a higher educational character than have yet been established. Success to every well-contrived endeavour! Yet their dependence must be on the power of truth; their armour must be that of righteousness; their weapons must be forbearance and sympathy. Let their many-hued hosts move on with a common object, not striving among themselves, and all ready to acknowledge the elements of good that are to be found, not only in Confucianism, but also in Tâoism and Buddhism.

Christianity has been working for nearly nineteen centuries in Europe, and yet the best of its populations is far from being a kingdom of our God, and His Christ. How long it will be before China, with its milleniums of history in the past and hundred-millioned population, will become such a kingdom we cannot tell; but while there is no harder life than that of a Chinese missionary, there is none more satisfying, none that should so stir the ambition of the most cultured and noblest-aimed of the educated youth of Christendom. 



\section{WORKS BY THE SAME AUTHOR.}

NOTIONS OF THE CHINESE CONCERNING Published GOD AND SPIRITS. . . . . $185^{2}$

THE CHINESE CLASSICS:-

I. CONFUCIAN ANALECTS, The Great Learning,

The Doctrine of the Mean. (Trübner \& Co.) . I86r

II. THE WORKS OF MENCIUS . . . . I86ז

III. THE SHU KING, or Book of Historical Documents . $\quad{ }_{1865}$

IV. THE SHE KING, or Book of Ancient Poetry . . 1871

v. THE CH'UN CH'TO, with the Tso Chrvan . . 1872

VI. THE HSIAOO KING, or Classic of Filial Piety. (In

'The Sacred Books of the East,' vol. iii.) . . . . $\quad 18 \pi 9$

VII. THE Yî KING, or Book of Changes. ('Sacred Books,' vol. xvi.) . . . . . . . . 1882

VIII. THE LA K $\hat{\ell}$, or Treatises on the Rules of Propriely.

('Sacred Books,' vols. xxvii, xxviii.) . . . . ${ }^{1885}$

LIFE AND TEACHINGS OF CONFUCIUS . . 1875

(Trübner \& Co.)

LIFE AND WORKS OF MENCIUS . . . 1875 (Trübner \& Co.)

THE SHE KING, or Book of Ancient Poetry in English Verse. (Trübner \& Co.) . . . . . 1876

THE RELIGIONS OF CHINA DESCRIBED AND COMPARED WITH CHRISTIANITY . . I88I (Hodder \& Stoughton.)

A RECORD OF BUDDHISTIC KINGDOMS, OR TRAVELS OF FÂ-HIEN .

(Clarendon Press, Oxford.) 